\title{
Aerosol measurements during COPE: composition, size, and sources of CCN and INPs at the interface between marine and terrestrial influences
}

\author{
Jonathan W. Taylor ${ }^{1}$, Thomas W. Choularton ${ }^{1}$, Alan M. Blyth ${ }^{2}$, Michael J. Flynn ${ }^{1}$, Paul I. Williams ${ }^{1,3}$, Gillian Young ${ }^{1}$, \\ Keith N. Bower ${ }^{1}$, Jonathan Crosier ${ }^{1,3}$, Martin W. Gallagher ${ }^{1}$, James R. Dorsey ${ }^{1,3}$, Zixia Liu ${ }^{1}$, and \\ Philip D. Rosenberg ${ }^{4}$ \\ ${ }^{1}$ Centre for Atmospheric Science, School of Earth and Environmental Sciences, University of Manchester, Manchester, UK \\ ${ }^{2}$ National Centre for Atmospheric Science, University of Leeds, Leeds, UK \\ ${ }^{3}$ National Centre for Atmospheric Science, University of Manchester, Manchester, UK \\ ${ }^{4}$ School of Earth and Environment, University of Leeds, Leeds, UK
}

Correspondence to: Jonathan W. Taylor (jonathan.taylor@manchester.ac.uk)

Received: 27 January 2016 - Published in Atmos. Chem. Phys. Discuss.: 4 February 2016

Revised: 20 July 2016 - Accepted: 20 July 2016 - Published: 21 September 2016

\begin{abstract}
Heavy rainfall from convective clouds can lead to devastating flash flooding, and observations of aerosols and clouds are required to improve cloud parameterisations used in precipitation forecasts. We present measurements of boundary layer aerosol concentration, size, and composition from a series of research flights performed over the southwest peninsula of the UK during the COnvective Precipitation Experiment (COPE) of summer 2013. We place emphasis on periods of southwesterly winds, which locally are most conducive to convective cloud formation, when marine air from the Atlantic reached the peninsula. Accumulation-mode aerosol mass loadings were typically $2-3 \mu \mathrm{g} \mathrm{m}^{-3}$ (corrected to standard cubic metres at $1013.25 \mathrm{hPa}$ and $273.15 \mathrm{~K}$ ), the majority of which was sulfuric acid over the sea, or ammonium sulfate inland, as terrestrial ammonia sources neutralised the aerosol. The cloud condensation nuclei $(\mathrm{CCN})$ concentrations in these conditions were $\sim 150-280 \mathrm{~cm}^{-3}$ at $0.1 \%$ and $400-500 \mathrm{~cm}^{-3}$ at $0.9 \%$ supersaturation (SST), which are in good agreement with previous Atlantic measurements, and the cloud drop concentrations at cloud base ranged from 100 to $500 \mathrm{~cm}^{-3}$. The concentration of $\mathrm{CCN}$ at $0.1 \%$ SST was well correlated with non-sea-salt sulfate, meaning marine sulfate formation was likely the main source of CCN. Marine organic aerosol (OA) had a similar mass spectrum to previous measurements of sea spray $\mathrm{OA}$ and was poorly correlated with $\mathrm{CCN}$.
\end{abstract}

In one case study that was significantly different to the rest, polluted anthropogenic emissions from the southern and central UK advected to the peninsula, with significant enhancements of OA, ammonium nitrate and sulfate, and black carbon. The CCN concentrations here were around 6 times higher than in the clean cases, and the cloud drop number concentrations were 3-4 times higher.

Sources of ice-nucleating particles (INPs) were assessed by comparing different parameterisations used to predict INP concentrations, using measured aerosol concentrations as input. The parameterisations based on total aerosol produced INP concentrations that agreed within an order of magnitude with measured first ice concentrations at cloud temperatures as low as $-12{ }^{\circ} \mathrm{C}$. Composition-specific parameterisations for mineral dust, fluorescent particles, and sea spray OA were 3-4 orders of magnitude lower than the measured first ice concentrations, meaning a source of INPs was present that was not characterised by our measurements and/or one or more of the composition-specific parameterisations greatly underestimated INPs in this environment. 


\section{Introduction}

Flash flooding occurs when rain is heavy and persistent. The southwest peninsula of the UK (shown in Figs. 1 and 2) is particularly prone to flash flooding because convective clouds form along convergence lines that often persist for many hours, as was the case in the Boscastle flash flood of August 2004 (Golding et al., 2005). This type of event develops when the wind blows from the southwest and aligns with the peninsula. Convergence associated with sea breeze fronts from the north and south coasts generates quasi-stationary convective systems (Warren et al., 2014). In the Boscastle case, individual cells moved with the wind, but new cells were constantly generated at the upwind end, causing the system as a whole to remain in a quasi-stationary position. Each cell developed over a similar timeframe, and they therefore precipitated over the same region, causing highly localised flooding. The potential of convective clouds to generate persistent and heavy rainfall, and consequent flooding, along the peninsula demonstrates the importance of understanding cloud formation and development in the region.

As convection is initiated in newly developing cells, boundary layer aerosols are lifted up to provide the cloud condensation nuclei $(\mathrm{CCN})$ necessary for cloud drop formation. Increased concentrations of larger and more soluble aerosols enhance $\mathrm{CCN}$ numbers and, consequently, enhance cloud drop number concentration (CDNC). This inhibits the formation of warm precipitation by reducing average drop size (Fan et al., 2007; Huang et al., 2008), which also affects riming efficiency in mixed-phase clouds (Klett and Davis, 1973). At sub-zero temperatures, aerosols provide the ice nucleating particles (INPs) required for primary ice formation, which may then lead to secondary ice processes such as the Hallett-Mossop rime-splintering processes (e.g. Huang et al., 2008; Phillips et al., 2001). Interactions between the warm rain and secondary ice processes are thought to be key to determining the timing and location of cold precipitation (Taylor et al., 2016). Aerosols may influence these processes by affecting cloud and drizzle drop size, and by determining the concentrations of primary ice forming at different cloud temperatures. Koren et al. (2005) found that convective clouds forming in polluted air may have a higher cloud fraction, lower ice fraction, and smaller droplet radius than those forming in clean Atlantic air.

In the prevailing west/southwesterly winds, Atlantic air influences the southwest peninsula, whereas in northerly or easterly winds the region receives anthropogenic pollution from the UK and western Europe. Local emissions from farming and transport may also influence aerosol over the peninsula.

The COnvective Precipitation Experiment (COPE; Leon et al., 2016) took place in the southwest peninsula during July-August 2013. Multiple aircraft conducted in situ measurements of aerosol and clouds, as well as airborne remote sensing measurements, on days predicted to be favourable
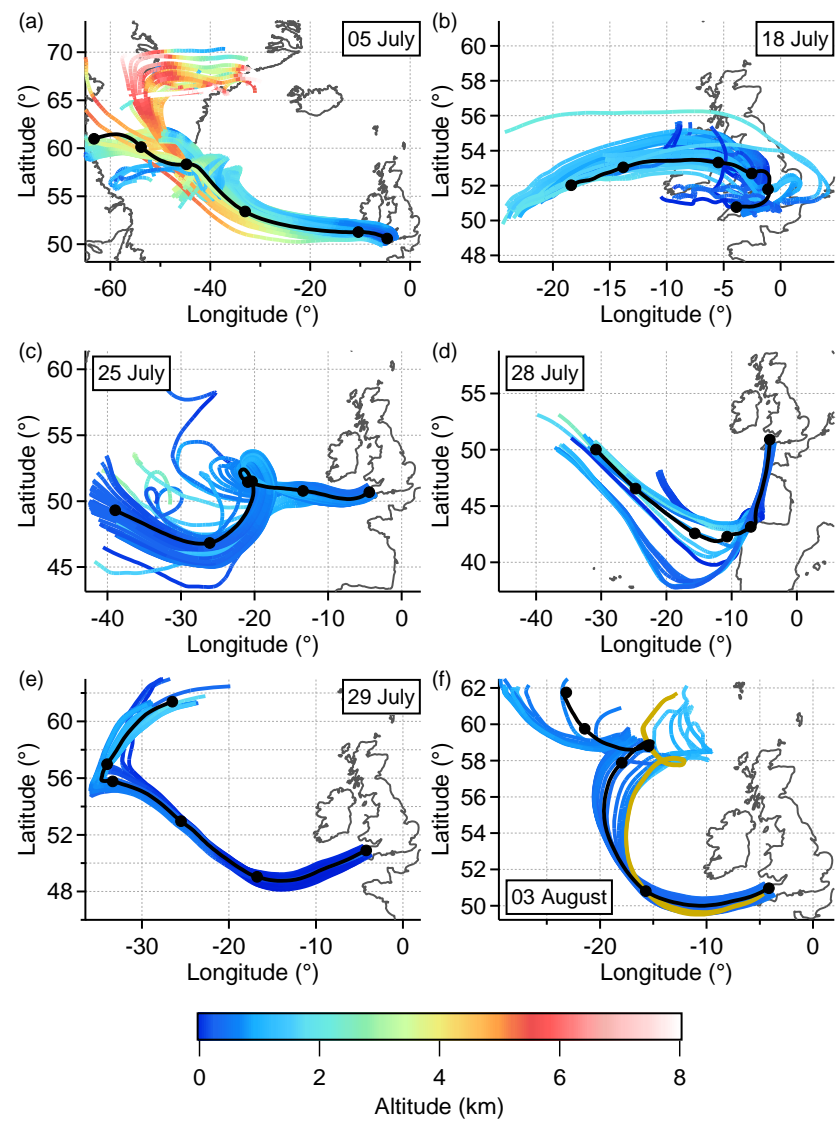

Figure 1. Five-day HYSPLIT back trajectories initiated over the southwest peninsula of the UK during the boundary layer aerosol runs. Panels (a-f) show the back trajectories on different flying days. Individual trajectories are coloured by altitude. The black lines show the mean trajectories, with markers every $24 \mathrm{~h}$ before sampling. The two gold lines in (f) (which lie approximately on top of each other on the plot) are the two trajectories released from the ground site at 11:00 and 12:00 UTC. The altitude of these two trajectories remained below $200 \mathrm{~m}$ in the first $48 \mathrm{~h}$, and below $1000 \mathrm{~m}$ in the $120 \mathrm{~h}$ of the runs.

for convective cloud formation. Additional ground-based aerosol and X-band radar measurements were performed throughout the duration of the experiment. The main aim of COPE was to improve quantitative precipitation forecasting in numerical weather prediction (NWP) models. Clark et al. (2016) describe state-of-the-art convection-permitting models, which are used operationally for rainfall forecasting both in the UK and elsewhere. The development and application of these NWP models requires the use of parameterisations for processes that would be too small in scale or too costly computationally to explicitly evaluate on an operational basis. A parameterisation may be used, for example, to calculate the autoconversion rate of cloud water to rain, rather than explicitly evaluating processes such as 

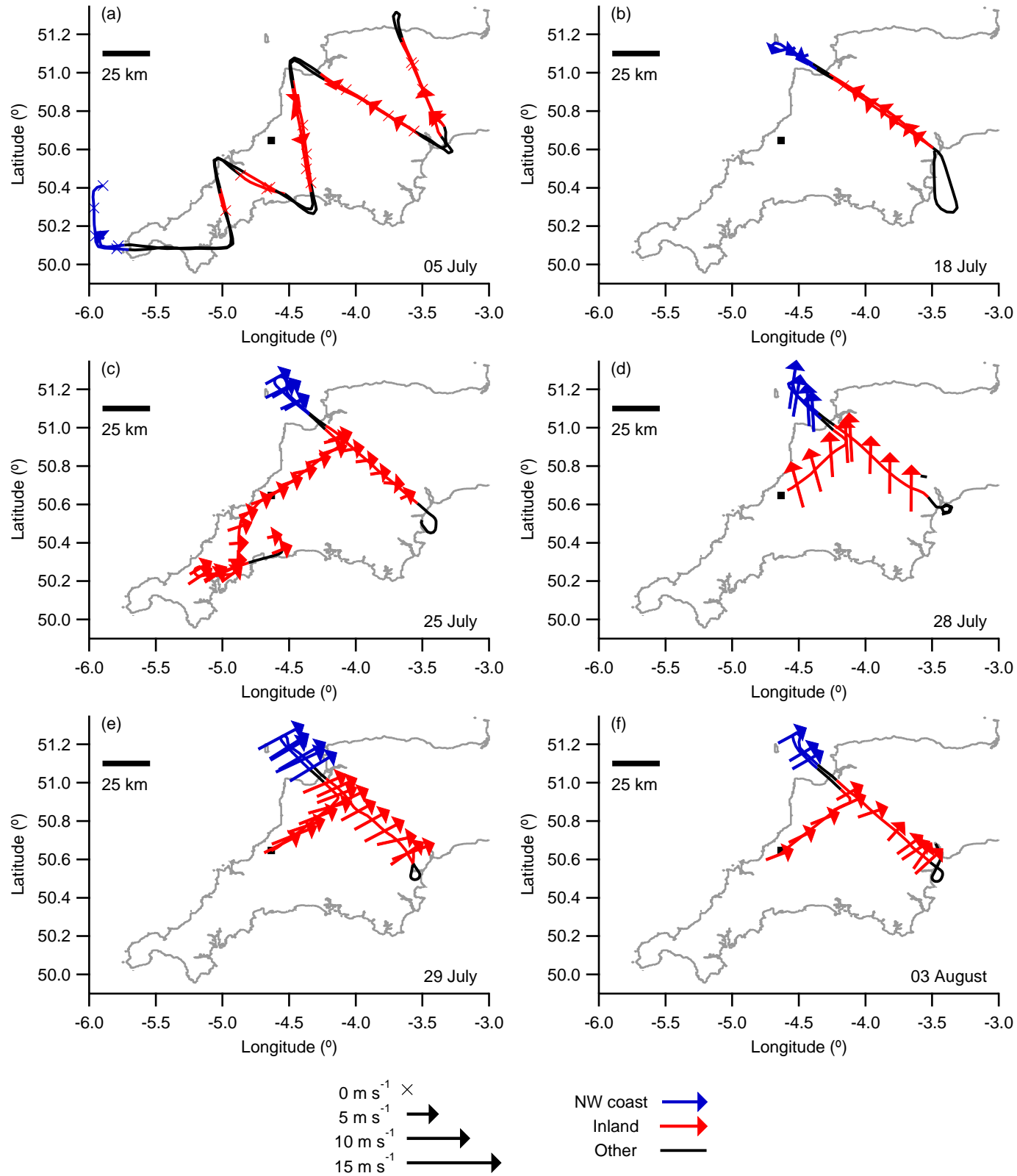

Figure 2. Spatial location of the below-cloud aerosol runs on each case study flight. Panels (a-f) show the six case study flights. The arrow markers show the measured wind speed and direction. The black square shows the location of the Davidstow ground site.

collision-coalescence, condensation, and evaporation over sub-grid timescales.

The development of improved parameterisations, and investigation of the relative importance of different processes, involves the use of more detailed research models. For example, Connolly et al. (2009) described the aerosol-cloudprecipitation interaction model (ACPIM), one of several research models which investigators will use as part of COPE analysis to study different cloud-aerosol interactions and microphysical processes. ACPIM requires information on aerosol composition and size distribution, as well as environ- mental variables, to initialise its explicit cloud microphysics scheme. The purpose of this paper is to describe the boundary layer aerosol measured during the aircraft campaign in terms of concentration, size, and composition, as well as determine the main sources of CCN and INPs, in order to inform modelling studies aiming to improve forecasts of convective precipitation in the region. Additional measurements of cloud microphysics (e.g. Taylor et al., 2016) may be used to evaluate the importance of different cloud microphysical processes, while the X-band radar measurements provide a 
dataset to evaluate the accuracy of the distribution and rate of precipitation in a regional model.

\section{Experimental}

\subsection{Aircraft measurements}

Most of the data used in this analysis were measured by instrumentation mounted on the UK BAe-146-301 Atmospheric Research Aircraft during six case study flights over the southwest peninsula, which took place between 5 July and 3 August 2013. Each flight had a designated flight number; these are listed in Table 1. Additional airborne measurements were performed with the University of Wyoming King Air 200T (UWKA) and UK Met Office Civil Contingency 208 Aircraft (MOCCA), but these are not discussed here. The BAe-146 was fitted with a variety of aerosol and cloud probes. Here we only discuss instruments relevant to our analysis; Leon et al. (2016) provide a full list of instrumentation aboard the aircraft. All concentrations are corrected to standard temperature $(273.15 \mathrm{~K})$ and pressure $(1013.25 \mathrm{hPa})$.

A typical flight plan involved performing below-cloud aerosol runs in the boundary layer before making measurements of clouds at higher levels. The flight paths of the boundary layer aerosol runs in each flight are shown in Fig. 2, and the altitude and duration of the aerosol runs are listed in Table 1. Vertical profiles of potential temperature showed the boundary layer height was $\sim 750-1250 \mathrm{~m}$ above mean sea level (a.m.s.l.; unless otherwise stated, all altitudes henceforth are a.m.s.l.), meaning these aerosol runs were conducted in the boundary layer.

The concentration of condensation nuclei $(\mathrm{CN}$, i.e. the aerosol number concentration) larger than $2.5 \mathrm{~nm}$ was measured using a model 3786-LP water-filled condensation particle counter (WCPC; Hering et al., 2005) manufactured by Aerosol Dynamics Inc., based on the TSI model 3786 but modified for use at low pressure. The accuracy of the $\mathrm{CN}$ concentration measurement is $\pm 12 \%$.

A Droplet Measurement Technologies (DMT) dualcolumn cloud condensation nuclei counter (CCNC; Roberts and Nenes, 2005) measured the concentrations of CCN at nominal supersaturations (SST) of 0.1 and $0.9 \%$, though on 18 July the higher SST was set to $0.6 \%$. The relative uncertainty in the supersaturation measurements is $\pm 10 \%$ (Roberts et al., 2010; Trembath, 2013), and the uncertainty associated with the flow calibration and counting efficiency of the particle counter is typically $\sim 6 \%$ (Trembath, 2013, p. 189). The CCNC sampled behind a pressure-controlled inlet set to $650 \mathrm{hPa}$.

The aerosol size distribution was measured with a custombuilt inboard scanning mobility particle sizer (SMPS; Wang and Flagan, 1990), a wing-mounted Particle Measurement Systems passive cavity aerosol spectrometer probe (PCASP)-100X, with electronics upgraded by DMT, and a

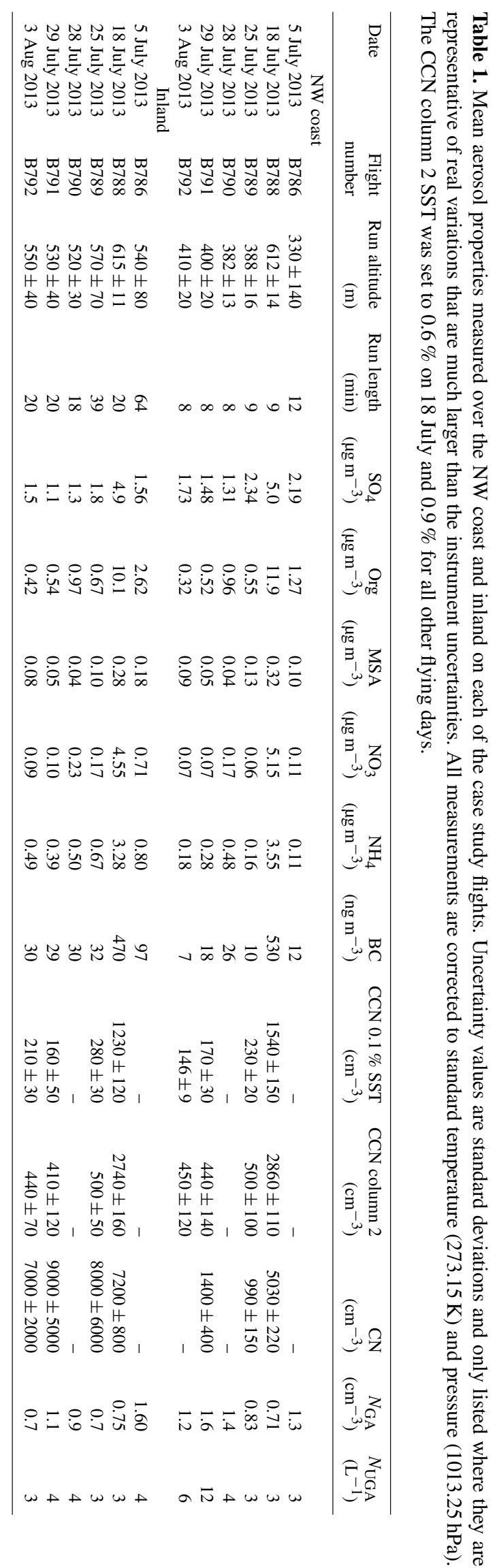

www.atmos-chem-phys.net/16/11687/2016/ 
DMT cloud droplet probe (CDP). The PCASP and CDP were size-calibrated as described by Rosenberg et al. (2012), and we assumed a refractive index of $n=(1.5-0 i)$ for the ambient aerosol. The SMPS measures the mobility diameter of particles 20-320 nm, while the PCASP and CDP measure the optical diameter of particles $0.12-3.4$ and $2-50 \mu \mathrm{m}$ respectively. The CDP measures aerosols and cloud drops at ambient humidity. The PCASP inlet has a dried sheath flow, and the SMPS inlet line was dried to $<45 \% \mathrm{RH}$ by ram heating and the temperature increase as the sample line entered the cabin. The SMPS data were normalised to the PCASP by scaling the SMPS concentrations in each bin so the concentrations in the overlap region matched those of the PCASP. As is shown in later analysis, the particles are composed predominantly of secondary aerosol and are likely to be quasispherical, meaning any shape correction for the SMPS distributions would be minimal. The difference in the size of the PCASP bins derived using a refractive index of $1.5 \mathrm{com}-$ pared to using values of 1.53 for ammonium sulfate and 1.44 for sulfuric acid is $\sim 5 \%$, which is equivalent to half a bin. Taking this difference into account when normalising the SMPS distributions gave a 3-6\% uncertainty in the normalised SMPS distributions.

The composition of nonrefractory submicron aerosol was measured with an Aerodyne Research Inc. compact time-offlight aerosol mass spectrometer (AMS; Canagaratna et al., 2007; Drewnick et al., 2005), which reports concentrations of organic aerosol (OA), sulfate $\left(\mathrm{SO}_{4}^{2-}\right)$, nitrate $\left(\mathrm{NO}_{3}^{-}\right)$, and ammonium $\left(\mathrm{NH}_{4}^{+}\right)$as standard. Additionally, we used the fragmentation table given by Langley et al. (2010) to calculate concentrations of methanesulfonic acid (MSA), and adjusted the fragmentation tables of $\mathrm{OA}$ and $\mathrm{SO}_{4}$ accordingly. The AMS can also be used to report chloride $\left(\mathrm{Cl}^{-}\right)$concentrations, which would be likely to be influenced by sea salt in a marine environment. Previous studies have attempted to quantify sea salt using the AMS, but the scaling factor used to correct the data for the instrument's poor detection efficiency of sea salt was highly variable (Nuaaman et al., 2015; Ovadnevaite et al., 2012; Schmale et al., 2013; Zorn, 2009). As no calibrations for sea salt were carried out in the field, we are unable to estimate the scaling factor, and thus the $\mathrm{Cl}^{-}$concentration, with any reasonable accuracy, and we therefore do not report $\mathrm{Cl}^{-}$concentrations in this analysis. The $\mathrm{SO}_{4}^{2-}$ measurement may have a contribution from sea-salt sulfate, but this is likely to be of the order of $1 \%$ (Schmale et al., 2013).

The AMS was calibrated at the start and end of each flight using monodisperse ammonium nitrate to calculate the ionisation efficiency (IE) for $\mathrm{NO}_{3}^{-}$, corrected as described by Morgan et al. (2015; Supplement). The ammonium nitrate calibrations were also used to calculate the relative ionisation efficiency (RIE) of $\mathrm{NH}_{4}^{+}$, and a separate ammonium sulfate calibration was performed to calculate the RIE of $\mathrm{SO}_{4}^{2-}$. The AMS IE calibration was stable within $\pm 12 \%$ throughout the campaign, and the absolute accuracy is $\sim 30 \%$ (Bahreini et al., 2009). The collection efficiency was calculated as recommended by Middlebrook et al. (2012), and the aerosol volume, calculated with volume mixing using organic and inorganic densities of 1.27 and $1.77 \mathrm{~g} \mathrm{~cm}^{-3}$ respectively (Cross et al., 2007), showed qualitative agreement with the aerosol volume measured by the SMPS and PCASP.

Refractory black carbon (BC) concentrations were measured with a DMT single-particle soot photometer (SP2; Schwarz et al., 2010), which is the same instrument used in previous studies on the BAe-146 (e.g. Taylor et al., 2014) but upgraded to be functionally identical to the current SP2 model D. SP2 calibrations were carried out at the start of each flight and in the laboratory after the campaign. The incandescence detectors, which measure $\mathrm{BC}$ mass on a singleparticle basis, were calibrated using $300 \mathrm{~nm}$ mobility diameter Aquadag, corrected for the difference in response between the calibration particles and ambient soot (Baumgardner et al., 2012; Laborde et al., 2012b). Using this calibration, the uncertainty in the reported $\mathrm{BC}$ mass concentrations is $\pm 10 \%$ when sampling diesel soot and $\sim 20 \%$ when sampling biomass burning (Laborde et al., 2012a, b).

The online inboard aerosol instrumentation (i.e. the AMS, SP2, SMPS, and CCNC) sampled using Rosemount inlets, which have sampling efficiencies of approximately unity for particles smaller than $600 \mathrm{~nm}$ in diameter when sampling marine aerosol (Trembath et al., 2012).

Bulk aerosol was collected on two $47 \mathrm{~mm}$ Nuclepore filters, with 10 and $1 \mu \mathrm{m}$ pore sizes, connected in serial. The filter sampling system is described by Formenti et al. (2008). The size and composition of particles collected on the filters was determined offline after the campaign by scanning electron microscopy, using a Phillips FEI XL30 environmental scanning electron microscope with field-emission gun (ESEM-FEG), with an energy-dispersive X-ray spectroscopy (EDX) system (Hand et al., 2010). Particles were classified by composition using the scheme described by Young et al. (2016). An example filter composition measurement from the COPE campaign is presented by Leon et al. (2016). In our analysis, we only use the filter measurements to estimate the concentration of mineral dust for use in INP parameterisations.

The $\mathrm{CO}$ concentration was measured using an AeroLaser VUV fluorescence monitor model AL5002 (Gerbig et al., 1999), and the 3-D wind vector was measured with a deiced Aventech aircraft-integrated meteorological measurement system (AIMMS)-20 turbulence probe (Beswick et al., 2008). A Stratton Park Engineering Company SPEC 2DS stereo probe was used to derive ice concentration, using the data processing rules described by Taylor et al. (2016).

\subsection{Ground site measurements}

The COPE ground site (located at $50.6466^{\circ} \mathrm{N}, 4.63323^{\circ} \mathrm{W}$ ) hosted a suite of aerosol and meteorological instrumentation 
operating continuously throughout July and August 2013. Leon et al. (2016) provide a full list of instrumentation at the ground site. The aerosol properties measured at the ground site followed the same trends as those measured aboard the BAe-146, though it is not in the scope of this paper to provide an in-depth comparison. In this analysis, we only use the size-resolved measurements of fluorescent aerosol made by a University of Hertfordshire wideband integrated bioaerosol sensor (WIBS) 4M, as this measurement was not available on the BAe-146.

The WIBS was mounted atop an $\sim 8 \mathrm{~m}$ high sampling tower. The particle size distribution in the range $0.4-12 \mu \mathrm{m}$ (optical equivalent diameter) is measured by light scattering at a wavelength of $635 \mathrm{~nm}$. When a scattering particle is detected, two xenon lamps fire sequential UV pulses at 280 and $370 \mathrm{~nm}$, which can cause fluorescent emissions that are detected in three channels measuring the ranges $310-400 \mathrm{~nm}$ (channel F1), 420-650 nm (channel F2), and 420-650 nm (channel F3) (Healy et al., 2012). We consider the fluorescent particles measured by the WIBS to be primary biological aerosol particles (PBAPs). Although the WIBS may also detect other fluorescent particles, the fluorescent particle concentration is generally considered to be a lower limit on the PBAP concentration (Huffman et al., 2010).

\section{Results}

\subsection{Air mass history}

Figure 1 shows 5-day back trajectories for each of the case study flights, calculated using the Hybrid Single Particle Lagrangian Integrated Trajectory Model (HYSPLIT) (Stein et al., 2015). Trajectories were initiated every $60 \mathrm{~s}$ from the aircraft flight track during the boundary layer aerosol runs. The trajectories were performed with 3-hourly $0.5^{\circ}$ Global Data Assimilation System (GDAS) reanalysis data, using full vertical dynamics on 23 model levels. Two additional trajectories were released from the ground site (at an altitude of $10 \mathrm{~m}$ above ground level) on 3 August at 11:00 and 12:00 UTC, the same time period as the aerosol runs, to provide context for the use of the ground site measurements in Sect. 4.3. These two ground-site trajectories follow a similar path to the ones released from the aircraft flight track on 3 August, meaning the aircraft and ground site were sampling from the same air mass on this date. Although the turbulent mixing in the boundary layer means the accuracy of individual trajectories is uncertain, examining the general trend provides information on the history of the air mass, as well as possible changes in its cloud nucleating potential, which is determined by synoptic-scale winds. Figure 2 shows the flight path the aircraft took during the below-cloud runs, and the boundary layer wind speed and direction measured during these runs. The wind data allow us to assess the accuracy and potential influence of the back trajectories' final stages, and examine local wind fields such as sea breeze circulations that are not captured by the meteorology data used to initiate the trajectories.

Figures 1 and 2 panels $\mathrm{c}$, e, and $\mathrm{f}$ show that the 25 and 29 July and 3 August case studies shared the synoptic features of the "Boscastle-type" meteorology, i.e. winds blowing marine air from the North Atlantic over the peninsula from the southwest (hereafter referred to as southwesterly winds (SWW)) (Golding, 2005). The back trajectories showed that the air masses had been over the North Atlantic for at least 5 days prior to landfall. They also showed sharp changes in direction over the ocean; comparison with UK Met Office synoptic charts (available at http://www1.wetter3. de/Archiv/archiv_ukmet.html) showed these were due to circulation around low-pressure systems as they moved east and were associated with frontal precipitation. This precipitation is likely to have washed out the majority of any long-range transported aerosol as the trajectories show the air mass remained in the lower troposphere, below the likely source of frontal precipitation. On 28 July, the situation was reasonably similar in that the air mass had spent time over the North Atlantic, but reached the peninsula from the south, and may have passed over the northwest tips of Spain and France. Local sea breeze circulations may still have caused convergence on these 4 days, but they had only a minor influence on the absolute wind speed and direction, as the synoptic-scale winds were so strong.

The meteorology on 5 and 18 July were markedly different to the other case studies. On these 2 days, high pressure systems located over the UK meant that synoptic-scale boundary layer winds were much weaker. The measured winds were generally only a few metres per second and the greater variation in wind direction suggests that the local sea breeze circulations had more of an influence on absolute wind direction on these days. On 5 July, the back trajectories show that, for the few days prior to being sampled, the air mass had passed over the Atlantic, though the easternmost trajectories passed over the southern tip of Ireland and the south coast of Wales. It is difficult to assess the accuracy of these parts of the trajectories when local winds were dominant, though there was some anthropogenic influence on this flight, as discussed in the next section. The trajectories for 18 July suggest the air over the peninsula had passed over many parts of England, Wales, and Ireland; therefore, this air is likely to have also had a strong anthropogenic influence.

The colours in Fig. 2 divide sections along the flight track into "northwest (NW) coast", "inland", and "other" influenced regions. The "NW coast" regions include areas over the sea, and the regions labelled "other" are not used in this analysis. Depending on the wind directions, aerosol in these regions may be influenced by marine or terrestrial emissions, or both. The trajectories and wind data in Figs. 1 and 2 show that, for flights on 5, 25, and 29 July and 3 August, the sections on the NW coast were affected by marine air that had not been influenced by land, though this was not the case for 
Table 2. Mean diameter of distinct aerosol modes measured over the NW coast and inland on the different case study flights.

\begin{tabular}{|c|c|c|c|}
\hline \multirow[b]{2}{*}{ Date } & \multicolumn{3}{|c|}{ Mean diameter $(\mu \mathrm{m})$} \\
\hline & Aitken mode & Accumulation mode & Coarse mode \\
\hline & NW coast & & \\
\hline 5 July & 0.048 & 0.188 & 3.92 \\
\hline 18 July & N/A* & 0.125 & 3.25 \\
\hline 25 July & 0.060 & 0.184 & 4.18 \\
\hline 28 July & 0.049 & 0.153 & 3.04 \\
\hline 29 July & 0.041 & 0.155 & 4.20 \\
\hline 3 August & 0.043 & 0.158 & 4.00 \\
\hline & Inland & & \\
\hline 5 July & N/A* & N/A* & 3.71 \\
\hline 18 July & N/A* & 0.114 & 3.13 \\
\hline 25 July & 0.055 & 0.169 & 3.76 \\
\hline 28 July & 0.051 & 0.145 & 3.56 \\
\hline 29 July & N/A* & 0.151 & 3.61 \\
\hline 3 August & 0.057 & 0.155 & 3.87 \\
\hline
\end{tabular}

* Mode not distinct from surrounding distribution.

the other two flights. Dividing the data into these sections allows us to investigate changes in aerosol chemistry and properties at the land-sea interface. This topic is discussed in detail in Sect. 4.1.2.

\subsection{Aerosol size distributions}

Figure 3 shows the submicron aerosol size distributions measured during the six case study flights. The standard deviations are plotted to show the spatial variation over the runs, which were much larger than the calculated standard errors for the size range shown. Three submicron aerosol modes are evident from the distributions: nucleation, Aitken, and accumulation modes, with varying magnitudes in the different flights. Coarse-mode aerosols were also measured, but the supermicron distributions are not shown in Fig. 3 as the bin sizing errors and overlap between the PCASP and CDP made the features difficult to distinguish. The mean diameters of the Aitken, accumulation, and coarse modes are listed in Table 2. The mean diameter of the nucleation modes was likely to be smaller than the SMPS can reliably measure.

Many of the measured distributions did not drop to near zero in the lowest bin, suggesting nucleation-mode aerosols were present smaller than the $20 \mathrm{~nm}$ cutoff of the SMPS. In all flights, the concentrations of particles in all bins $<40 \mathrm{~nm}$ in diameter was higher inland than over the sea. Additionally, the total CN concentration (listed in Table 1) was always higher and more variable inland, and the standard deviations of the smallest particles measured were higher inland. These measurements suggest there was a source of small particles forming inland, which was not uniform in spatial location.

On most flights, the Aitken mode was centred on 40$60 \mathrm{~nm}$, and the accumulation mode was centred around 115$190 \mathrm{~nm}$. The gap in between was characteristic of the "Hop- pel dip", thought to be caused by cloud processing of marine aerosol (Hoppel et al., 1986). Similar size distributions have been measured in summertime North Atlantic aerosol (Asmi et al., 2011; Dall'Osto et al., 2011). The accumulation mode on 5 July was larger, with modal diameter $\sim 275 \mathrm{~nm}$ on the PCASP over the sea, which may be due to increased photochemical aerosol formation in the clear weather. July 18 was also an exception, showing just one wide accumulation mode both over the NW coast and inland, and the size distribution was consistent with aged UK urban aerosol (e.g. Bohnenstengel et al., 2015) with the air mass having come from the east. The features of the marine aerosol size distribution seen on other days, such as a prominent Aitken mode and Hoppel dip, were also absent on this day due to the lack of a marine influence.

It is also of interest to examine the concentrations of giant (dry diameter, $1 \leq D_{\mathrm{p}} \leq 10 \mu \mathrm{m}$ ) and ultragiant particles $\left(D_{\mathrm{p}}>10 \mu \mathrm{m}\right)$, as these may have an enhanced effect on precipitation formation via the warm rain process (Johnson, 1982), and our observations may be used to inform modelling studies (e.g. Blyth et al., 2013). The number concentrations of giant $\left(N_{\mathrm{GA}}\right)$ and ultragiant $\left(N_{\mathrm{UGA}}\right)$ aerosols are listed in Table 1. $N_{\mathrm{GA}}$ varied by around a factor of 2 between cases, with values of around one per cubic centimetre, but there was no obvious trend to explain the differences between the different days. For the SWW cases, the inland $N_{\mathrm{GA}}$ was fairly proportional to the NW coastal values, but lower by $15-40 \%$. These marine particles are likely to be sea spray aerosols, and indeed sea salt made up nearly $80 \%$ of supermicron aerosol volume on 3 August (Leon et al., 2016). Additionally, on these days the mean diameter of the coarse aerosol was larger over the NW coast than inland. These measurements are consistent with dilution/deposition of sea salt particles inland being greater than any terrestrial coarse aerosol emissions such as PBAPs or dust on these days.

The concentrations of ultragiant aerosol also showed around a factor of 2 variation between the different cases, and were $3-6 \mathrm{~L}^{-1}$, other than the NW coastal measurement on 29 July, which was $11 \mathrm{~L}^{-1}$. Again, it is difficult to pick out any clear trend in the values. On some days, $N_{\mathrm{UGA}}$ was higher over the sea, whereas on others it was higher inland. In all cases, $N_{\mathrm{GA}}$ and $N_{\mathrm{UGA}}$ comprised a very small fraction of the total aerosol number concentration.

\subsection{Submicron aerosol composition}

\subsubsection{Marine aerosol}

Figure 4 shows the average aerosol composition measured by the AMS and SP2 in the NW coastal regions during the six case study flights. The data from Fig. 4 are also listed in Table 1. In clean Atlantic air (NW coast on 5, 25 and 29 July and 3 August, as identified in the previous section) the composition was fairly consistent. The total mass loadings measured by the AMS $+\mathrm{SP} 2$ varied from 2.4 to $3.8 \mu \mathrm{g} \mathrm{m}^{-3}$ in 

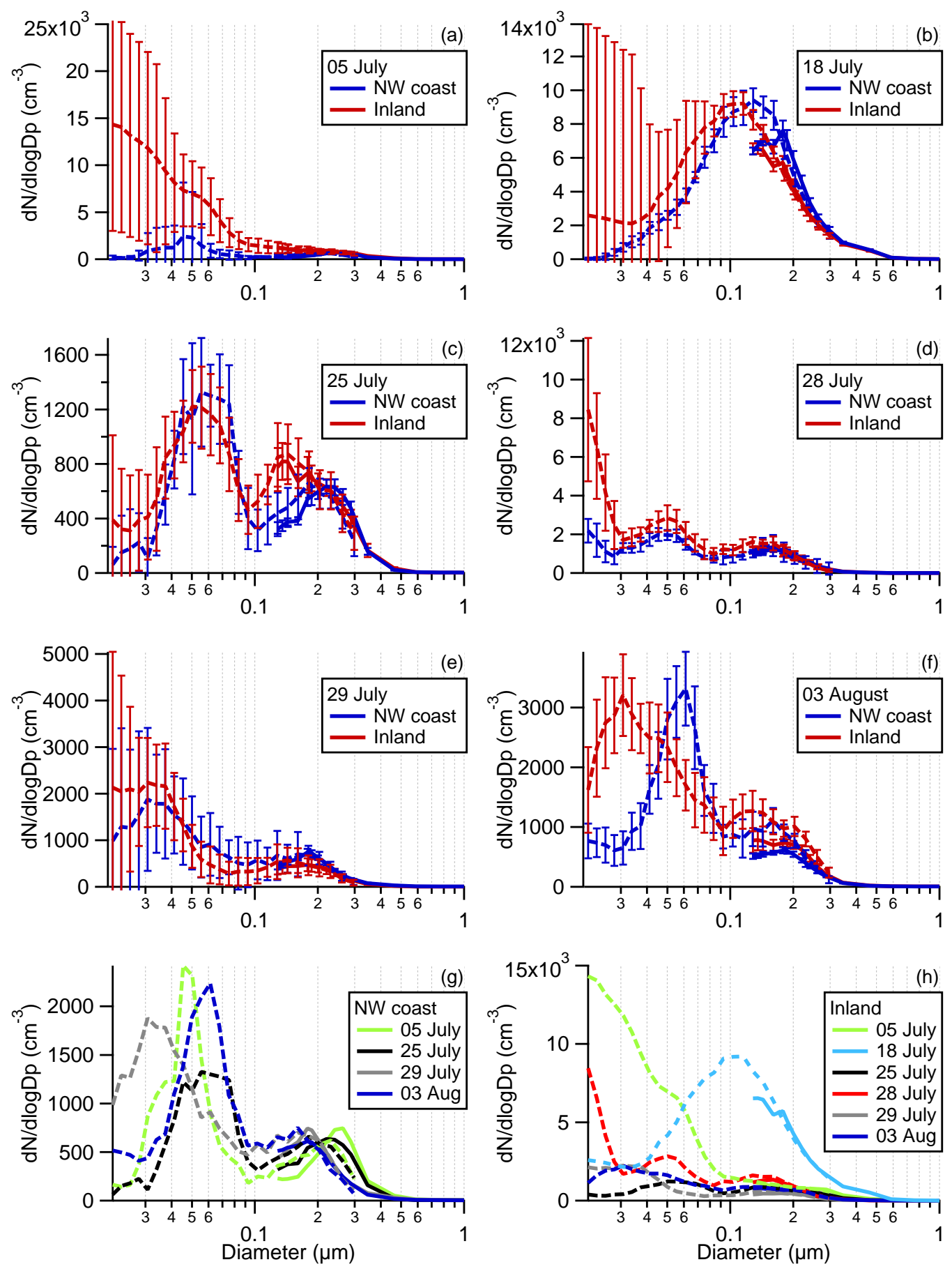

Figure 3. Submicron aerosol size distributions measured by the SMPS (dashed lines) and PCASP (solid lines) probes aboard the BAe-146. Panels (a)-(f) show the inland and NW coast distributions for each of the case study flights, while (g) and (h) show comparisons of all the NW coast and inland distributions respectively. The error bars in (a)-(f) show the standard deviations over each measurement period.

these flights. Around $60-70 \%$ of submicron aerosol mass was sulfate, in the form of a mixture of sulfuric acid and ammonium bisulfate as there was insufficient ammonium for full neutralisation. This is in agreement with measurements of North Atlantic aerosol made by Ovadnevaite et al. (2014).
The aerosol acidity, investigated here in terms of sulfate neutralisation, influences gas-particle partitioning. For example, nitrate aerosol cannot stably coexist when internally mixed with particle-phase sulfuric acid but may do so with ammonium sulfate. 


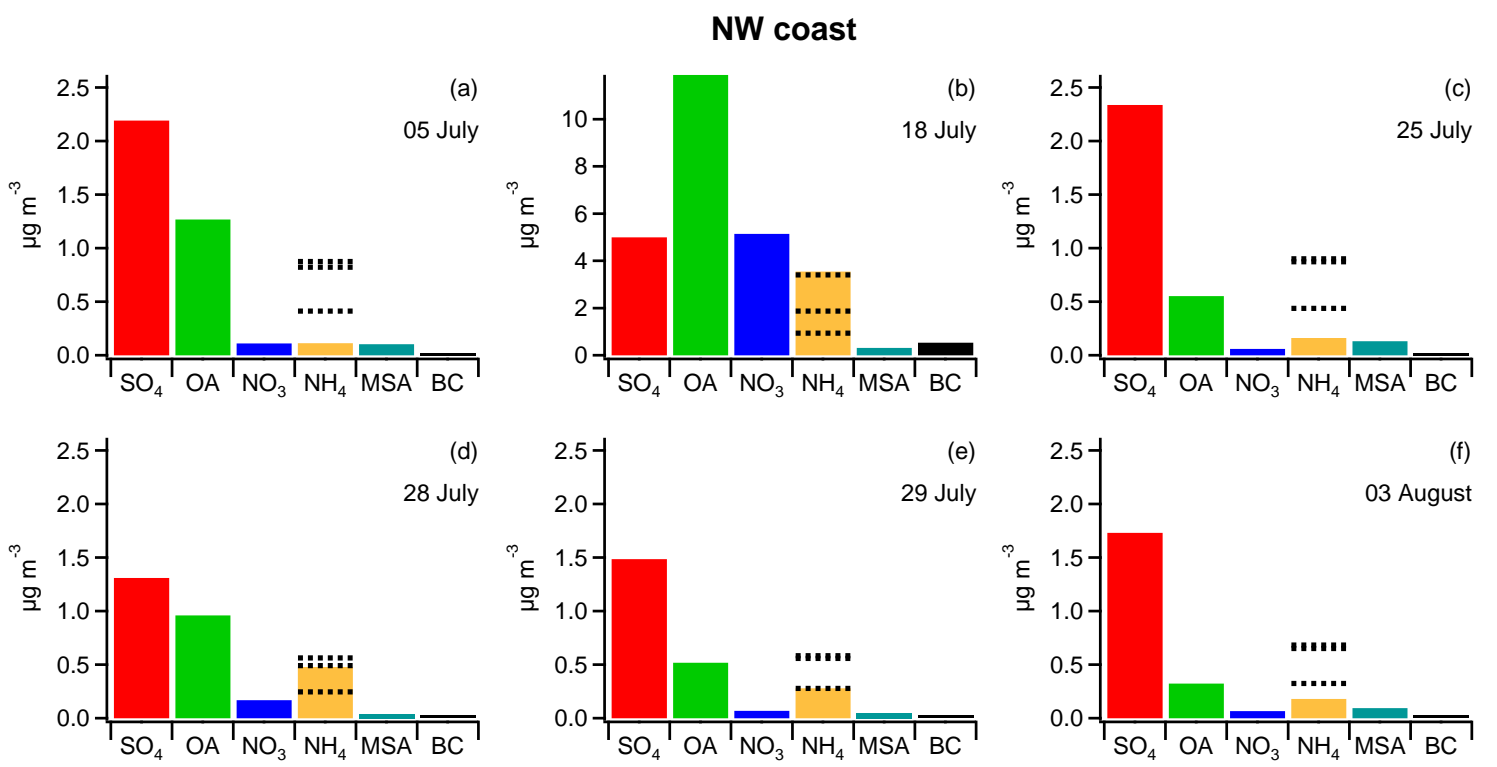

Figure 4. Aerosol composition measured over the NW coast during the six case study flights. The definitions of each chemical species are given in Sect. 2.1. The lower and middle dashed lines show the concentration of $\mathrm{NH}_{4}$ required to neutralise the $\mathrm{SO}_{4}$ to ammonium bisulfate and sulfate respectively. The top dashed line shows the concentration of $\mathrm{NH}_{4}$ required to fully neutralise all measured inorganic components. The reader should consult in Sect. 3.3.4 for discussion of the $\mathrm{NO}_{3}$ measurements.

In the marine air masses, the ratio of MSA $/ \mathrm{SO}_{4}$ was $\sim 0.05$, which is perhaps lower than average but within the range typically observed in clean marine air in summer (e.g. Dall'Osto et al., 2010; Huebert et al., 1996; Ovadnevaite et al., 2014; Phinney et al., 2006). MSA and sulfate were well correlated $\left(R^{2}=0.66\right)$, and the source of both is likely to be oxidation of biogenic dimethyl sulfide (DMS) emissions. OA was the only other major submicron aerosol component, though the ratio of $\mathrm{SO}_{4} / \mathrm{OA}$ did show some variation. It is unlikely that anthropogenic pollution, either from shipping or long-range transport, made any significant contribution to the aerosol loadings; in clean Atlantic air, the OA showed no correlation with $\mathrm{BC}\left(R^{2}=0.0\right)$, while $\mathrm{SO}_{4}$ showed a weak negative correlation $\left(R^{2}=0.15\right)$. These results are in agreement with a similar assessment of Atlantic aerosol made at Mace Head, Ireland (O'Dowd et al., 2014). The source of the marine OA is discussed further in Sect. 3.3.3.

Black carbon was only a minor component and low, but non-zero, levels of nitrate were measured, despite the fact that aerosol nitrate is not expected to form in acidic conditions as the sulfate displaces any nitrate to the gas phase. Interpretation of this apparent measured nitrate is discussed in Sect. 3.3.4.

\subsubsection{Inland aerosol}

Submicron inland aerosol composition on flying days is shown in Fig. 5. On flying days between 25 July and $3 \mathrm{Au}-$ gust, inland aerosol had composition similar to the Atlantic marine air, but with the addition of ammonium. On 25 and
28 July, the ammonium was sufficient to fully neutralise the sulfate, but on 29 July and 3 August, the sulfate was a mixture of ammonium sulfate and bisulfate. The total measured mass loadings were within $10 \%$ of the marine air for the corresponding flight.

Compared to the last four flights, the inland aerosol on 5 July had a much larger OA fraction. The low wind speeds on this day mean local aerosol sources are likely to have had more of an effect. Inland on 5 July, OA had a correlation with $\mathrm{BC}$ of $R^{2}=0.56$, and with the aircraft's CO measurement an $R^{2}=0.69$. Additionally, the $\mathrm{BC}$ mass loading was around a factor of 10 higher inland than in the Atlantic air. Taken together, these suggest that local fossil fuel emissions were at least partly responsible for the increased OA inland on 5 July. Some of the easternmost trajectories passed over the southern tips of Wales and Ireland, which are an alternative source of the increased anthropogenic influence inland on 5 July.

July 18 was somewhat of an outlier in terms of the COPE case studies in that the aerosol mass loadings were much higher than the other flying days. The back trajectories showed that the air mass had come from England, Wales, and/or Ireland, so a strong anthropogenic influence would be expected, in contrast to the clean marine air from the southwest seen in the other cases. There was not much difference between the aerosol measured inland and on the NW coast, as the air over both areas had come from the east, bringing anthropogenic pollution to the region. OA was the largest component, followed by similar amounts of ammonium nitrate and sulfate, which were both fully neutralised by ammonium. 


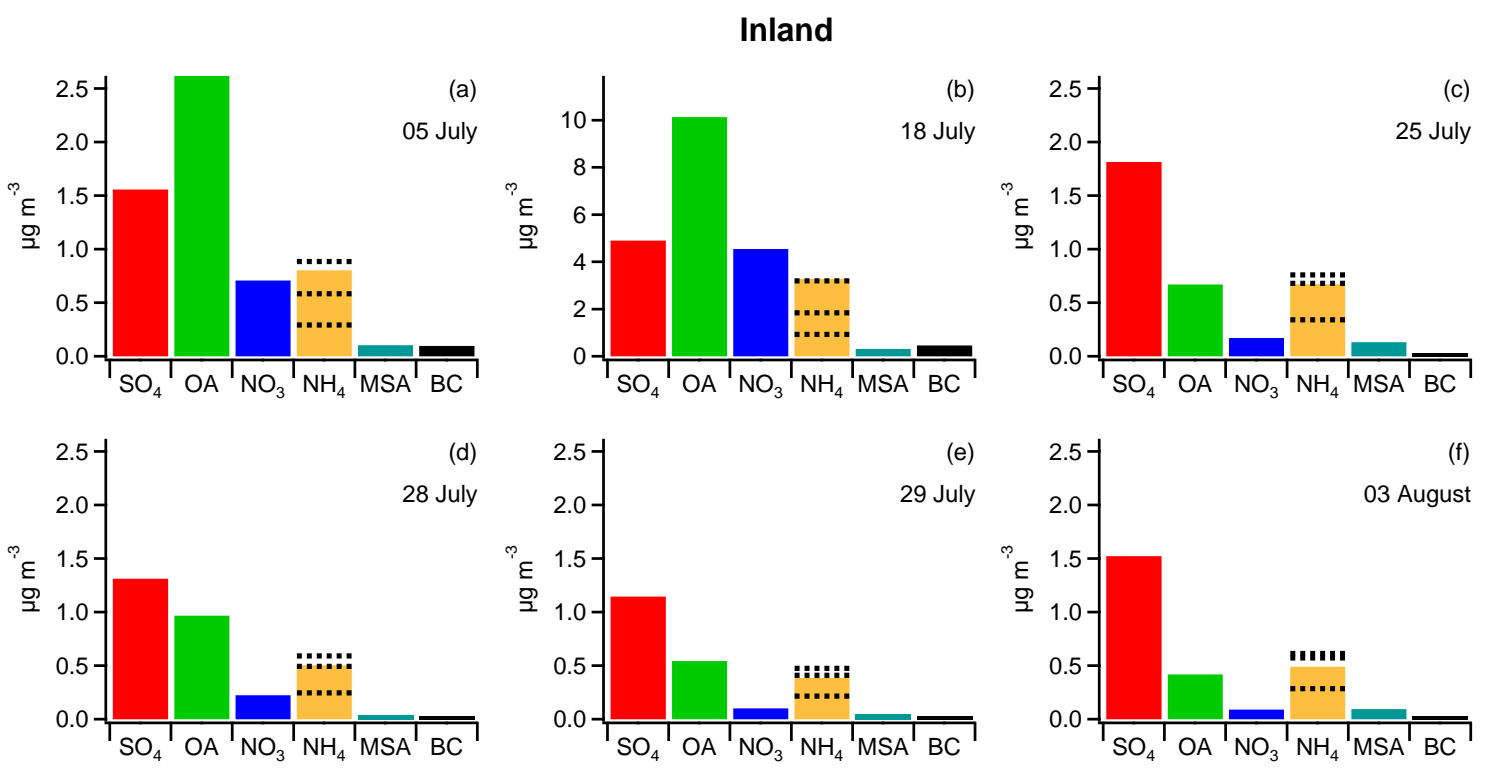

Figure 5. As in Fig. 4 but for measurements taken inland over the southwest peninsula of the UK.

\subsubsection{OA composition and origin}

Examining the ratios of different fragments in the OA mass spectrum can give an indication of OA sources as well as their level of ageing. AMS factor analysis most commonly tends to pick out factors with differing levels of oxidation. Fresh fossil fuel emissions appear as hydrocarbon-like OA (HOA), while more aged aerosol including secondary OA (SOA) appears as oxygenated OA (OOA), which may be semi-volatile (SV-OOA) or more aged low-volatility (LVOOA) (Jimenez et al., 2009).

OA measured in marine background air may be primary OA from sea spray (Ovadnevaite et al., 2011), SOA from marine volatile organic compound (VOC) emissions (Decesari et al., 2011), or long-range transported pollution. Globally, primary marine OA is thought to dominate over marine SOA formation (Arnold et al., 2009; Gantt and Meskhidze, 2013). As discussed in Sect. 3.3.2, local anthropogenic emissions contribute to OA concentrations inland, while marine OA would have less of an influence in areas further away from the sea.

The OA mass spectrum measured over the NW coast on 5 July is shown in Fig. 6. The spectrum is dominated by peaks at $m / z 28$ and 44 from $\mathrm{CO}^{+}$and $\mathrm{CO}_{2}^{+}$, which are prescribed to be equal in the default fragmentation table. As is typical in oxidised OA spectra, these peaks are much larger than $m / z 43$ from $\mathrm{C}_{3} \mathrm{H}_{7}^{+}$or $\mathrm{H}_{3} \mathrm{C}_{2} \mathrm{O}^{+}$, as the $\mathrm{CO}^{+}$and $\mathrm{CO}_{2}^{+}$ions are more likely to be formed by fragmentation of more oxidised organic molecules. Table 3 presents correlations between NW coast OA spectra from 5, 25, and 29 July and 3 August, and several spectra from literature. The literature spectra are HOA and two OOA factors (Morgan et al., 2010); sea spray (Ovadnevaite et al., 2011); marine bio-

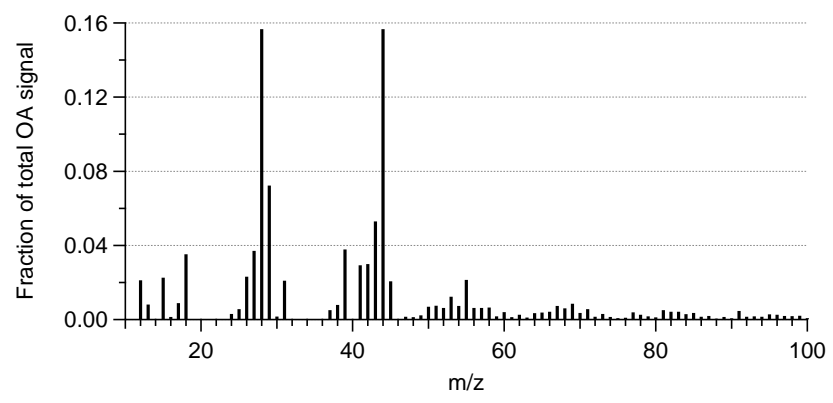

Figure 6. Normalised mass spectrum of marine OA measured over the NW coast on 5 July.

genic SOA (Chang et al., 2011), which was well correlated with $\mathrm{SO}_{4}$; and the "organic factor" measured in the Arctic Ocean by Chang et al. (2011), which was thought most likely to be sea spray OA and was poorly correlated with sulfate. Though there are many previous measurements of different OA components in Europe, we choose those from Morgan et al. (2010) because they were measured with the same instrument aboard the BAe-146, so any inter-instrument variability should be minimised. OOA-1 was more oxidised than OOA2 , but no assessment was made of their volatility. To ensure the comparison was fair, only $m / z$ values where all spectra had data points were used. The marine OA spectra showed the best correlation with sea spray OA, indicating this is a likely source, though the correlations with the other oxidised factors were still reasonably good.

Figure 7 shows the fractions $f_{44}$ and $f_{43}$ (the fraction of OA measured at $m / z 44$ and 43 respectively) for all six case study flights, divided up into NW coastal and inland data. 
Table 3. Uncentred $R$ (also known as normalised dot product) between marine OA measured on the SWW case studies and several literature spectra. $m / z, 28$ was not used for the correlations due to gas-phase interference.

\begin{tabular}{|c|c|c|c|c|c|c|}
\hline \multirow[b]{2}{*}{ Date } & \multicolumn{6}{|c|}{ Uncentred $R$} \\
\hline & Sea spray ${ }^{1}$ & Marine biogenic $\mathrm{SOA}^{2}$ & Organic factor ${ }^{2}$ & $\mathrm{HOA}^{3}$ & OOA-1 ${ }^{3}$ & OOA- $2^{3}$ \\
\hline 5 July & 0.99 & 0.84 & 0.99 & 0.47 & 0.81 & 0.83 \\
\hline 25 July & 0.97 & 0.89 & 0.97 & 0.51 & 0.78 & 0.83 \\
\hline 29 July & 0.99 & 0.79 & 0.98 & 0.38 & 0.83 & 0.79 \\
\hline 3 August & 0.95 & 0.85 & 0.96 & 0.46 & 0.79 & 0.79 \\
\hline
\end{tabular}

${ }^{1}$ Ovadnevaite et al. (2011), ${ }^{2}$ Chang et al. (2011), ${ }^{3}$ Morgan et al. (2010).

The literature values from Table 3 are also plotted. Ambient OOA measurements tend to fall within the diagonal dashed lines in Fig. 7 (Ng et al., 2010), and fossil fuel emissions may be expected to fall close to the HOA point from Morgan et al. (2010) upon emission and progress approximately through OOA-2 to OOA-1 with increased oxidation.

The four marine spectra from this study have $f_{44}$ indicative of a moderate level of oxidation but, on average, slightly low $f_{43}$. Of the selected literature values, the marine OA points all fall closest to the sea spray OA, rather than the marine biogenic. If the inland OA was composed of a mix of marine and terrestrial OA, lines drawn from the marine data points through their corresponding inland points should intersect in a region representative of terrestrial OA. For the four flights with clean marine spectra, the lines would intersect in a region around $(0.1,0.1)$, close to the SV-OOA data point from Morgan et al. (2010). This is consistent with the terrestrial aerosol source being similar on each flying day, as well as being moderately oxidised.

It is not fully clear what fraction of the terrestrial OA is anthropogenic or biogenic. It is difficult to pick out anthropogenic locally produced SOA from biogenic as the mass spectra look similar, and photochemical production is strongest for both during peak daylight hours. Most AMS factor analysis studies are only able to pick out regional background and locally produced OOA (Jimenez et al., 2009, and references therein). Slowik et al. (2010) identified a biogenic SOA factor by correlation with biogenic VOCs, but they noted the mass spectrum was very similar to SVOOA formed from anthropogenic pollution. As discussed in Sect. 3.3.2, the correlation between $\mathrm{OA}$ and $\mathrm{CO}$ is indicative of a fossil fuel component of the terrestrial OA, but we also cannot rule out a biogenic component.

\subsubsection{Interpretation of nitrate measurements}

The formation of nitrate aerosol is only possible when there is sufficient ammonium (or other cations) to fully neutralise any sulfate aerosol (Seinfeld and Pandis, 1998). However, our observations in Figs. 4 and 5 show the apparent presence of aerosol nitrate under acidic conditions. The measurements are above the detection limit for nitrate $\left(\sim 0.03 \mu \mathrm{g} \mathrm{m}^{-3}\right.$ for a

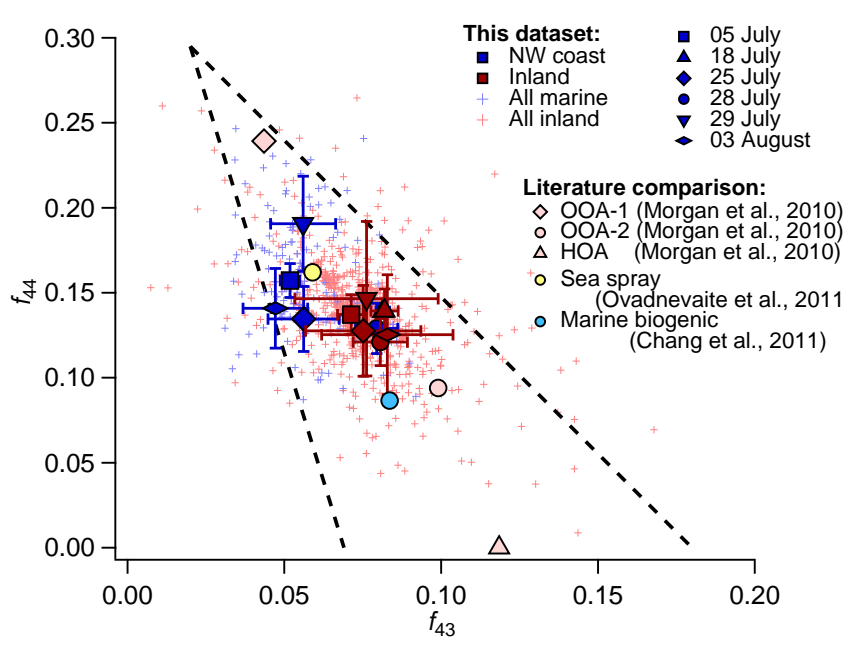

Figure 7. Relationship between the fraction of OA signal at $(m / z)=44$ and 43 , in coastal and inland areas. The diagonal dotted lines define the region where ambient OOA measurements tend to fall ( $\mathrm{Ng}$ et al., 2010). The data points labelled "All marine" are the NW coast data from 5, 25, and 29 July and 3 August, whereas the points labelled "All inland" are from all six flights. The literature spectra are the same as those in Table 3.

$30 \mathrm{~s}$ averaging time) and are ubiquitous throughout the runs, meaning they are not an artefact of averaging two air masses of differing composition.

Nitrate appears in the AMS almost entirely in peaks at $m / z=30$ and 46 (Allan et al., 2003), for ions $\mathrm{NO}^{+}$and $\mathrm{NO}_{2}^{+}$respectively. When sampling nitrate species, the ratio of these two peaks is determined by the heater temperature and aerosol volatility. For a fixed heater temperature, less volatile nitrate species decompose further during their slower vaporisation, and have a higher 30 / 46 ratio when measured (Drewnick et al., 2015). The AMS may detect other nitrate species including salts such as $\mathrm{NaNO}_{3}$ and $\mathrm{KNO}_{3}$, as well as organic nitrates, as long as their boiling point is low enough.

Table 4 shows the ratios of $m / z 30 / 46$ measured on each flying day during ammonium nitrate calibrations and ambient sampling periods. For 18 July, the $30 / 46$ ratio was the same during the calibration and coastal/inland aerosol. As the 
Table 4. Comparison of the $m / z 30 / 46$ ratios measured in the AMS aboard the BAe-146.

\begin{tabular}{lrrr}
\hline Date & \multicolumn{3}{c}{$(m / z 30) /(m / z 46)$ ratio } \\
\cline { 2 - 4 } & $\left(\mathrm{NH}_{4}\right) \mathrm{NO}_{3}$ calibration & $\mathrm{NW}$ coast & Inland \\
\hline 5 July & 1.77 & 6.33 & 2.78 \\
18 July & 1.65 & 1.67 & 1.66 \\
25 July & 1.48 & 6.61 & 3.05 \\
28 July & 1.51 & 4.40 & 3.14 \\
29 July & 1.37 & 7.84 & 6.15 \\
3 August & 1.33 & 8.68 & 4.01 \\
\hline
\end{tabular}

ammonium in these periods was sufficient to fully neutralise the aerosol, this gives us a high degree of confidence that the $\mathrm{NO}_{3}$ measured on this flight was ammonium nitrate. However, on all other flights the ambient 30 / 46 ratio was higher than the calibration values, particularly over the sea. Sea-saltbased nitrates may be found in marine air, such as $\mathrm{NaNO}_{3}$ formed by reaction of nitric acid with $\mathrm{NaCl}$. This would be found predominantly in coarse-mode aerosol rather than accumulation mode (Harrison and Pio, 1983), but some particles may be detected by the AMS. Alfarra (2004) measured nebulised $\mathrm{NaNO}_{3}$ and recorded a $30 / 46$ ratio of 29.2, which is significantly higher than those measured during COPE. Presumably, the same argument applies with these nitrate salts as with ammonium nitrate: the nitrate would be displaced by sulfate unless the aerosol was fully neutralised. $\mathrm{NaNO}_{3}$ would only be possible if the coarse-mode aerosol was not in equilibrium with the accumulation mode. We must therefore investigate the possibility of organic compounds giving signals at the same $m / z$ as the nitrate peaks.

Ovadnevaite et al. (2011) measured high-resolution mass spectra of primary marine OA, which allowed them to identify the specific ions measured at particular $m / z$ values. Around $1.7 \%$ of primary marine $\mathrm{OA}$ was measured at $m / z 30$, most of which was $\mathrm{CH}_{2} \mathrm{O}$, and $0.2 \%$ was at $m / z 46$. If the measured nitrate concentrations in COPE were attributable to organic species, they would make up $6-12 \%$ of organic mass in marine air when corrected for relative ionisation efficiency. Rollins et al. (2010) measured 30 / 46 ratios of 0.99-5.30 for various organonitrates, which is more in line with our measurements.

To summarise, we are not able to conclusively explain the reported nitrate measurements in acidic conditions. Several past studies have faced similar problems in various different regions (e.g. Allan et al., 2004, 2006, 2014). It is likely that they are partly due to interference from organic species, but the inland $30 / 46$ ratios, where enhanced ammonium concentrations were measured, were closer to those expected from $\mathrm{NaNO}_{3}$. The measurements would need to be performed with a high-resolution mass spectrometer to confirm the organic fraction at the nitrate peaks. There may also be a contribution from sea-salt-based nitrate species such as
$\mathrm{NaNO}_{3}$, but these are also difficult to quantify with our measurements. On all flights other than 18 July, the total nitrate loadings were a relatively small fraction of the total mass measured by the AMS, as the $\mathrm{SO}_{4}$ and $\mathrm{OA}$ loadings were both several times higher.

\section{Discussion}

\subsection{Interactions between meteorology and aerosol properties}

\subsubsection{Contrasts between marine and polluted air masses}

Of the results outlined in the previous section, the main contrasts in aerosol properties were between the cleaner SWW cases and the pollution event measured on 18 July. In the SWW cases, the aerosol advected to the peninsula from the Atlantic was typical of marine aerosol in terms of its composition and size distribution. The mean aerosol mass loadings measured by the AMS over the NW coast on these days all agreed within $30 \%$, and the relative fractions of the different chemical species were also similar, with marine sulfate dominating. The $\mathrm{CN}$ concentrations over the NW coast (listed in Table 1) were only available on 25 and 29 July, but the integrated SMPS size distributions from Fig. $3 \mathrm{~g}$ also agreed within $30 \%$, and the peak sizes of each of the aerosol modes were also consistent.

In contrast, the easterly winds on 18 July brought anthropogenic pollution to the region, which increased the submicron aerosol mass loadings by an order of magnitude. There were higher loadings of all species, particularly OA, which was the dominant species during the pollution episode, and has a mass spectrum more similar to aged urban emissions compared to the marine OA measured in the other cases. The number concentration of aerosols in the accumulation mode on 18 July was significantly higher than on any of the other days studied, due to the anthropogenic pollution influence, and the $\mathrm{CN}$ concentration over the NW coast was several times higher than the cleaner cases. The concentration of particles in the inland nucleation mode on 5 July was also higher than on any of the other flights, and this mode was broader than the other flights, which may be due to the stagnant winds allowing photochemical processing to occur within the air mass with minimal mixing of clean marine air. However, most of the pollution is likely to be advected from urban areas further east, rather than emitted locally and allowed to build up, as the southwest peninsula of the UK is not a large source region of urban pollution. Other than these two flights, where fossil fuel emissions had a larger effect than the other case studies, the size distribution and composition of the accumulation-mode aerosol, which are of most relevance to cloud-forming particles, were fairly consistent. 


\subsubsection{Terrestrial and marine influences}

Section 3 highlighted some differences observed between aerosol properties in the same air mass measured over the NW coast or inland. When the cleaner marine air masses made landfall, the sulfuric acid was partially or fully neutralised to form ammonium sulfate, and in the case of 28 July this persisted to the NW coast measurements which were downwind of the landmass. Agriculture is the largest land use category in the southwest peninsula (Morton et al., 2011), including a mix of both arable and pastoral farming, predominantly cattle grazing on managed grass fields. Previous measurements have found elevated levels of ammonia in the southwest peninsula compared to those found in the Atlantic (Quinn et al., 1996; Sutton et al., 2001). The terrestrial ammonia emissions are therefore most likely to be of agricultural origin.

By replacing the $\mathrm{H}^{+}$ions with $\mathrm{NH}_{4}^{+}$, the neutralisation of the marine sulfuric acid inland should add to the inorganic mass, causing a marginal increase in average particle size. However, the corresponding increases in inorganics were balanced out by similar decreases in $\mathrm{SO}_{4}$ inland, and no consistent differences were observed between the corresponding aerosol size distributions.

One clear feature of the terrestrial influence was the presence of nucleation-mode aerosols inland. As shown in Fig. 8a, in all cases the inland $\mathrm{CN}$ concentration was significantly higher than that measured over the sea, and higher than typical marine concentrations in the absence of nucleation events (Dall'Osto et al., 2011; Jensen et al., 1996). The aerosol size distributions also showed concentrations of particles $<40 \mathrm{~nm}$ in diameter were always higher inland. Coastal nucleation is unlikely to explain these measurements, as there was no bias in concentrations towards coastal regions.

It is possible that the formation of these particles is also linked to agricultural emissions. Although particle formation rates from $\mathrm{H}_{2} \mathrm{SO}_{4}-\mathrm{NH}_{3}-\mathrm{H}_{2} \mathrm{O}$ ternary nucleation are lower than those observed in ambient environments, ternary nucleation involving other agricultural emissions (such as amines) may explain our results (Almeida et al., 2013; Pirjola et al., 2000). The high standard deviation / mean ratio of the inland $\mathrm{CN}$ concentrations in SWW suggests the process was spatially variable, rather than ubiquitous throughout the boundary layer.

\subsection{Aerosol influence on $\mathrm{CCN}$ and cloud drop concentrations}

\subsubsection{Linking $\mathrm{CCN}$ and $\mathrm{CDNC}$}

CCN data were only available on 18, 25, and 29 July and 3 August. Figure 8b shows the average boundary layer CCN concentrations measured on these flights, as well as a comparison to CDNC measured in updraughts near cloud base.
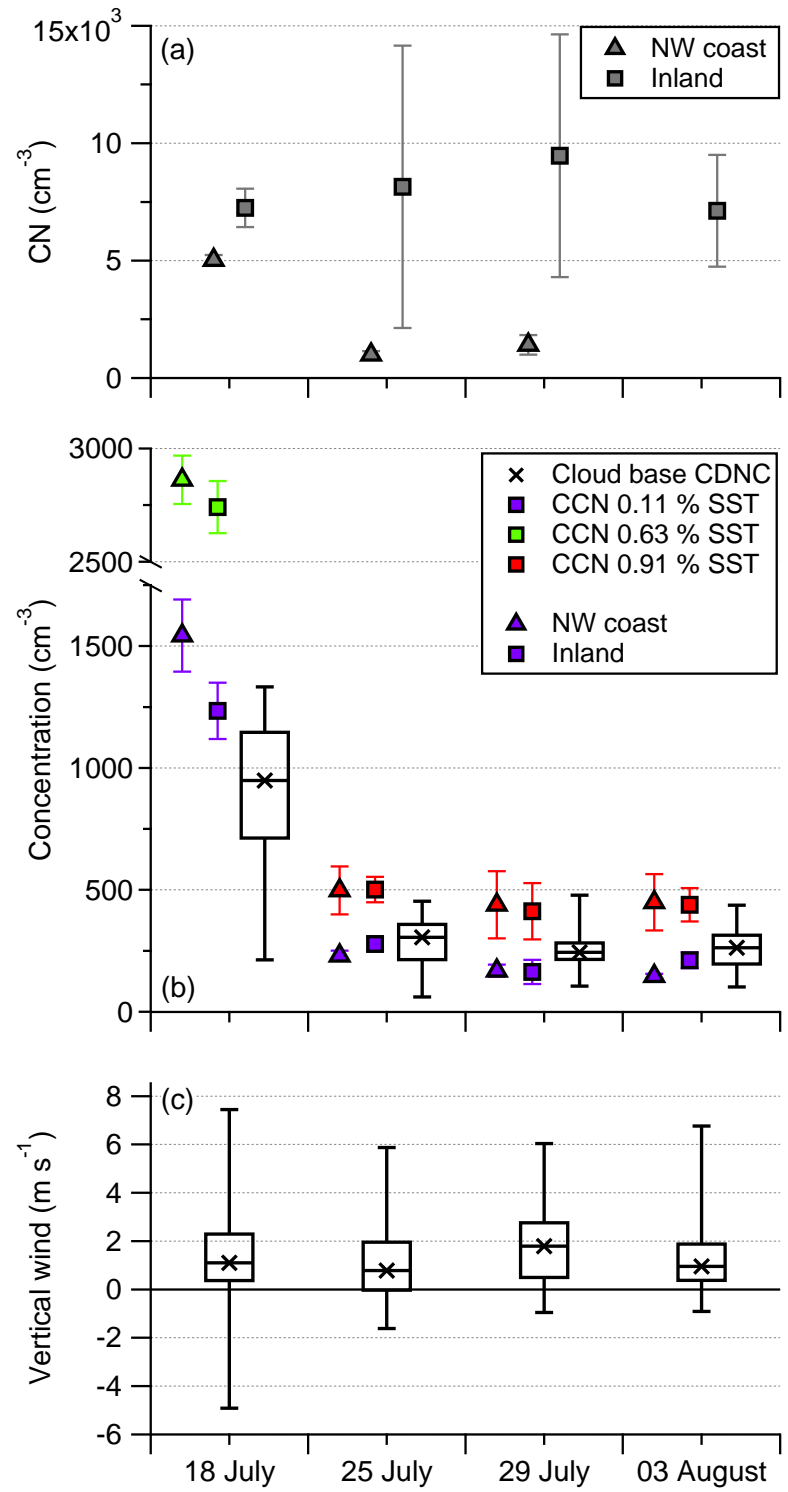

Figure 8. Comparison of particle concentrations measured in marine air (triangles) and inland (squares). Panel (a) shows the $\mathrm{CN}$ concentrations, while (b) compares the $\mathrm{CCN}$ concentrations to the CDNC measured in updraughts $>2 \mathrm{~m} \mathrm{~s}^{-1}$ within $500 \mathrm{~m}$ of cloud base. The boxes and whiskers show the 25/75th percentiles and the maximum/minimum. Panel (c) shows the distribution of vertical wind in cloud penetrations (liquid water content $>0.01 \mathrm{~g} \mathrm{~m}^{-3}$ ) within $500 \mathrm{~m}$ of cloud base.

Figure 8c shows the in-cloud distribution of vertical wind near cloud base; we use an updraught threshold of $2 \mathrm{~m} \mathrm{~s}^{-1}$, which is around the 75th percentile of cloud base vertical wind on the four flights shown. By choosing only data in updraughts, as well as excluding data from cloud edges, we aim to minimise the influence of entrainment, though it is unlikely to be eliminated. The higher values of CDNC are those 
least influenced by entrainment, and those with the strongest updraughts when the cloud formed.

The $\mathrm{CN}$ and $\mathrm{CCN}$ concentrations showed no correlation, and the fraction of $\mathrm{CN}$ active as $\mathrm{CCN}$ varied from 2 to $50 \%$. This fraction was largest on 18 July, when the average particle size was the largest of all the flights. On all flights, the $\mathrm{CCN}$ fraction was lower inland than over the NW coast. This was especially true of the SWW cases, where it was limited to single-figure percentages even at $0.9 \%$ SST. The majority of additional inland particles were too small to act as CCN. In these cases, the aerosol size distributions were a more important factor than the $\mathrm{CN}$ concentrations for determining $\mathrm{CCN}$ concentrations.

On 18 July, the peak CDNC was close to the $\mathrm{CCN}$ concentration at $0.1 \%$ SST. For the SWW flights, the peak CDNC was more comparable to the $\mathrm{CCN}$ concentrations measured at $0.9 \% \mathrm{SST}$, though the median CDNC was between the two $\mathrm{CCN}$ measurements, which is reasonable based on previous estimates of SST in cumulus clouds. For example, Politovich and Cooper (1988) calculated SST up to $\sim 0.3 \%$ in cloud passes with a high fraction of air from near cloud base.

Comparing $\mathrm{CCN}$ measured inland and over the sea, the differences were generally $<10 \%$, with the largest being $30 \%$. There was no clear systematic difference between land and sea. The addition of ammonium inland did not always increase inorganics, as the change was not always larger than the inherent variability in the $\mathrm{SO}_{4}$. On an air mass level, there appears to be an aerosol influence on cloud drop concentrations - the higher aerosol concentrations in the polluted air caused higher $\mathrm{CCN}$ concentrations. This difference was also manifested in the CDNC, which was several times higher in the polluted case on 18 July.

Dall'Osto et al. (2010) reported measurements of aerosol composition and $\mathrm{CCN}$ at Mace Head, Ireland, during late spring and early summer. Mace Head shares similarities with the southwest peninsula of the UK in that it experiences Atlantic air under the prevailing westerly winds but is also a receptor site for aged urban pollution during easterlies. The CCN concentrations on 18 July were around double those measured by Dall'Osto et al. (2010) in continental pollution, though the aerosol mass loadings here were also significantly higher. In marine air masses, the CCN concentrations at Mace Head were $\sim 200 \mathrm{~cm}^{-3}$ at $0.1 \%$ SST and $\sim 400 \mathrm{~cm}^{-3}$ at $1.0 \%$ SST. These numbers are both in good agreement with our measurements in the SWW cases.

\subsubsection{Aerosol chemistry, $\mathrm{CN}$, and $\mathrm{CCN}$}

In marine air, $\mathrm{CCN}$ may be produced by sea spray or condensation of secondary aerosols, predominantly $\mathrm{SO}_{4}$. These processes can interact, for example primary sea spray may subsequently be coated with $\mathrm{SO}_{4}$. Particles produced by sea spray may be composed of sea salt, OA, or a combination of the two, with OA more dominant in submicron particles (Cavalli et al., 2004). Sea salt is an effective CCN; OA from sea spray is likely to be insoluble (Gershey, 1983) but may be internally mixed with sea salt and/or serve as a condensation nucleus for secondary organic or inorganic aerosol formation. During runs over the southwest peninsula, terrestrial emissions may also have influenced CCN concentrations.

As an air parcel cools as it rises, there may be some cocondensation of semi-volatile species such as ammonium nitrate or SV-OOA, which may further enhance CCN concentrations (Topping et al., 2013). As the aerosol inlets on board the BAe-146 do not reliably sample aerosol during cloud penetrations, we are unable to assess how much of an impact this made, but we note that sulfuric acid/ammonium sulfate (the largest aerosol component in most case studies) is not semi-volatile at the temperatures sampled.

As the source functions of sea spray and secondary organic and inorganic marine and terrestrial aerosols all depend on different factors, they would not be expected to be correlated. Therefore, by comparing the measured $\mathrm{CCN}$ concentrations to different chemical species, we may gain information on the sources of the CCN.

Figure 9 shows the relationships between $\mathrm{CCN}$ concentrations measured aboard the BAe-146 at $0.1 \%$ SST and the PCASP number concentration, AMS total mass, non-sea salt inorganics, and OA. Although the validity of the nitrate measurement is unclear on some flights, the nitrate fraction on these days was low. The data in Fig. 9 are split between the three SWW case study flights and the polluted case of 18 July. If we did not make this distinction, all the variation and correlation coefficients would be dominated by the difference between the marine and polluted air masses, rather than variations in concentration within these air masses.

The correlation between CCN and aerosol number concentration measured by the PCASP was good, and the data fell close to the $1: 1$ line, meaning the critical diameter was close to the PCASP's lower cutoff of $\sim 120 \mathrm{~nm}$. Good correlations $\left(R^{2}>=0.66\right)$ were found in both marine and inland environments comparing $\mathrm{CCN}$ with total AMS mass and inorganics. The correlations with OA were lower, but non-zero, and the OA correlation in marine air was better than inland. These results are consistent with the main source of $\mathrm{CCN}$ being accumulation-mode sulfate-containing particles in both marine and inland air. Liu et al. (1996) found a similar correlation with sulfate at $0.06 \%$ SST for cloud-processed aerosol. We also investigated correlations between the $x$ variables in Fig. 9 and the CCN concentrations at $0.9 \%$ SST, but the correlations were not as good. This is likely to be because smaller particles activate at $0.9 \% \mathrm{SST}$, which are less associated with particle mass and may be smaller than the PCASP's detection range.

While our data suggest that the average $\mathrm{CCN}$ were composed primarily of $\mathrm{SO}_{4}$, they do not provide information on the origin of these particles. For example, marine $\mathrm{SO}_{4}$ may condense onto primary sea spray OA particles, which are largely insoluble when initially formed (O'Dowd and de Leeuw, 2007). Pierce et al. (2007) showed that this type of 

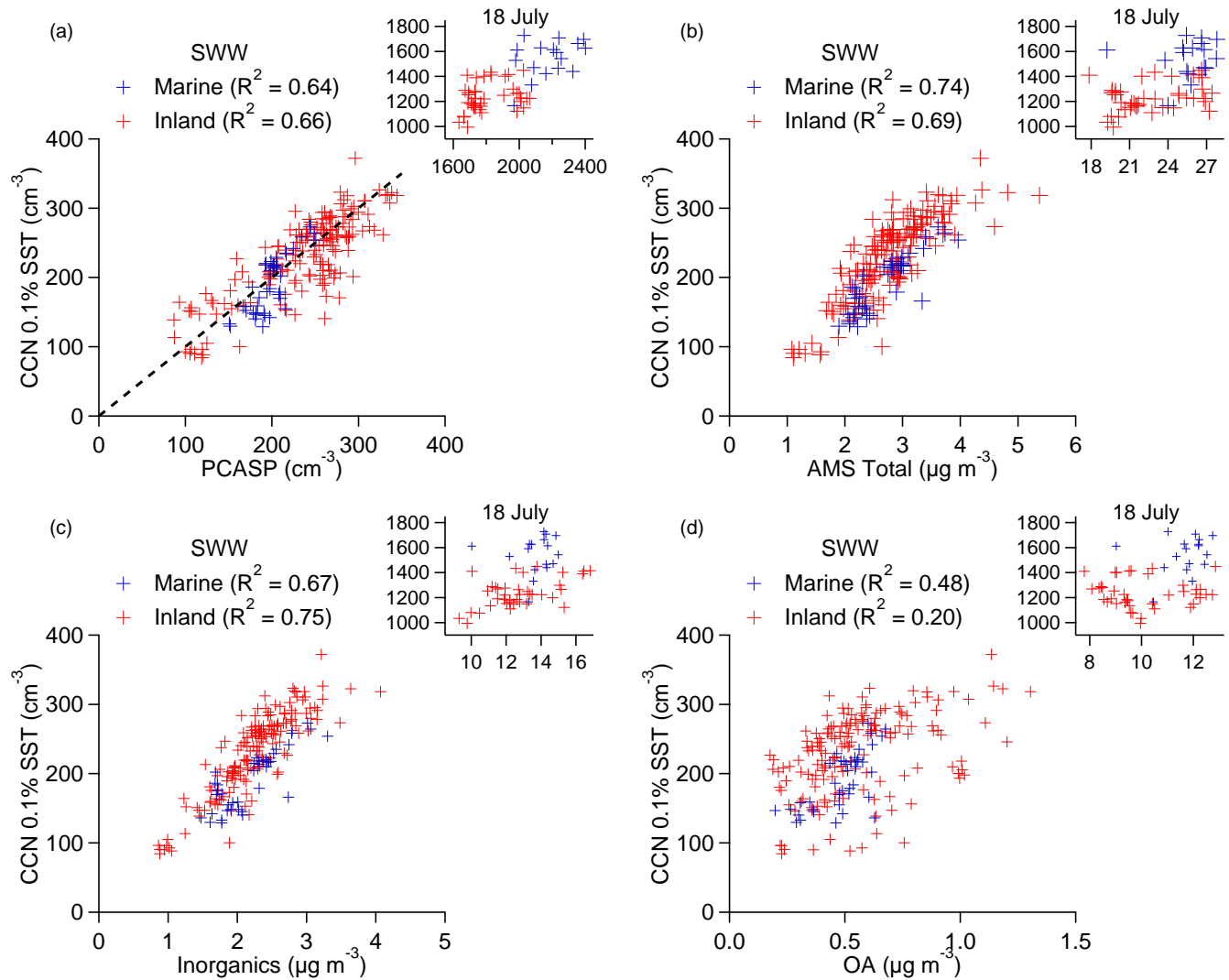

Figure 9. Scatter plots of measured CCN concentration at $0.1 \%$ SST with concentrations of aerosol species. The data shown are from 18 , 25, and 29 July and 3 August, as CCN data were only available on these days. The blue data points were measured over the NW coast, and the red points were measured inland, as defined in Fig. 2. Data from the SWW and anthropogenic pollution (18 July) cases are separated due to the different meteorological conditions and greatly differing $\mathrm{CCN}$ concentrations.

process can significantly enhance $\mathrm{CCN}$ concentrations globally by providing a surface for sulfuric acid to condense onto. Particle emissions from sea spray are strongly linked to wind speed (O'Dowd et al., 1997). This would mean the marine particle concentrations on 29 July would likely be the highest due to the stronger wind speeds, as shown in Fig. 2. While the marine $\mathrm{CN}$ concentration on 29 July was higher than on 25 July, it is difficult to draw firm conclusions from such a limited comparison.

Shipping emissions may also serve as condensation nuclei for secondary aerosol (e.g. Langley et al., 2010), but the low BC concentrations in our case studies suggest this was of little importance. Alternatively, new particles may form through nucleation of gas-phase precursors, and open-ocean nucleation events are thought to be most likely related to biological activity (O'Dowd et al., 2010). We gain some insight into particle formation by comparing to the size distributions classified as "clean marine" and "open-ocean nucleation" by Dall'Osto et al. (2011), measured at Mace Head. In particular, the value of $\mathrm{d} N / \mathrm{d} \log D_{\mathrm{p}}$ in our lowest size bin (20 nm) is a useful comparison for the smallest particles, which have experienced the least secondary growth. On 5 and 25 July, the values of the lowest size bin were $\sim 100 \mathrm{~cm}^{-3}$, which is consistent with the "clean marine" values $\left(\sim 80-150 \mathrm{~cm}^{-3}\right)$. The concentration on 29 July was higher at $985 \mathrm{~cm}^{-3}$, which is closer to that in "open-ocean nucleation" air masses $(\sim 800$ $2500 \mathrm{~cm}^{-3}$ ), but the value on 3 August of $516 \mathrm{~cm}^{-3}$ fell between the two categories. It is therefore not clear what contribution primary and secondary aerosol formation had overall to the aerosol number concentration in marine air, but the majority of $\mathrm{CCN}$ mass was composed of $\mathrm{SO}_{4}$, which must be secondary.

This leads us to the conclusion that, in the SWW cases, the main factors determining $\mathrm{CCN}$ concentrations were the size and composition of marine aerosols reaching the peninsula. The majority of accumulation-mode aerosol measured by the AMS in these cases was $\mathrm{SO}_{4}$. The measured $\mathrm{CCN}$ also exhibited a high degree of correlation with inorganics, which were predominantly $\mathrm{SO}_{4}$ and its cations. If this correlation were entirely due to the mixing of two homogeneous air masses, the OA would also show a similar degree of correlation with $\mathrm{CCN}$; however, the $R^{2}$ values for OA were much lower. The data therefore show that whatever process is responsible for the production of sulfate is also largely responsible for deter- 
mining the concentration of $\mathrm{CCN}$. Our results are consistent with the prevailing theory that the majority of marine $\mathrm{CCN}$ are composed of $\mathrm{SO}_{4}$ formed from DMS oxidation (Charlson et al., 1987).

\subsection{Sources of INPs}

The concentrations of primary ice and the temperatures at which they develop are a large source of uncertainty in the timeline of cloud glaciation. During COPE, the lowest cloudtop temperatures were $\sim-15^{\circ} \mathrm{C}$ (Taylor et al., 2016). Reviews by Hoose and Möhler (2012) and Murray et al. (2012) identified the only species that have been shown to behave as INPs in laboratory experiments at these temperatures as mineral dust; PBAPs such as bacteria (Diehl et al., 2006), fungal spores, and pollen (Pouleur et al., 1992); and black carbon, although the latter is relatively inefficient. Emissions data for bacteria and fungal spores are limited, but global model studies on clouds and precipitation including these species acting as INPs suggest a small but significant zonal influence on precipitation rates (Spracklen and Heald, 2014). Their concentrations at cloud formation levels are generally much lower than mineral dusts, though there is evidence that ice-active biological material internally mixed with mineral dust and may enhance the ice nucleating potential of the dust (Augustin-Bauditz et al., 2016). Recently, attention has also focused on marine surface organics, which may be aerosolised as sea spray (Burrows et al., 2013).

Mineral dust concentration and size distribution were measured using the BAe-146 filter system by combining the "silicates" and "mixed silicates" categories described by Young et al. (2016). Leon et al. (2016) show a more detailed breakdown of the composition of particles from 3 August. BC and OA concentrations were measured online using the SP2 and AMS. There was no instrument capable of isolating PBAPs aboard the aircraft, but the ground site hosted a WIBS, which made measurements of UV auto-fluorescent particles. The reader should see Sect. 2 for further details of the instrumentation.

In the absence of INP measurements, parameterisations must be used to calculate INP concentrations. These are empirical relationships derived by comparing measurements of INPs and various chemical species. Figure 10 shows comparisons of several parameterisations, as well as measured first ice concentrations from COPE. The aerosol measurements and ice concentrations used in Fig. 10 are from 3 August, as this day had the best measurements of ice formation, as presented by Taylor et al. (2016). The measured ice concentrations are from a series of penetrations through a cloud in the early stages of development, when secondary ice processes were thought to have at most a minor influence on ice concentrations (Taylor et al., 2016).

DeMott et al. (2010) based a parameterisation (hereafter D10) for INP concentrations on the total concentration of aerosol larger than $0.5 \mu \mathrm{m}\left(D_{\mathrm{p}}>0.5 \mu \mathrm{m}\right)$, derived from INP

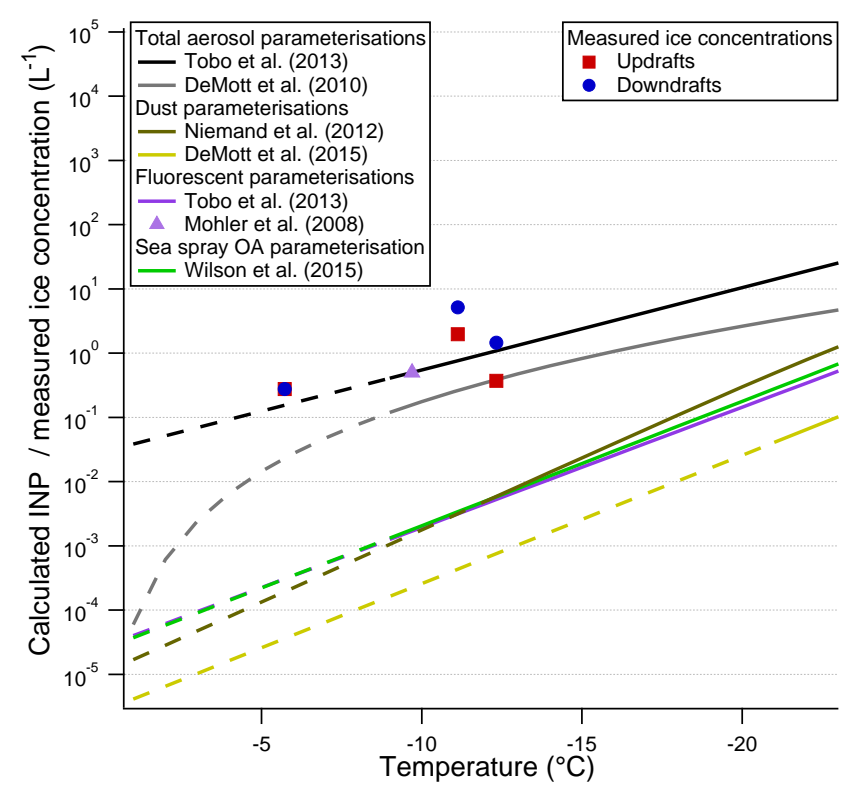

Figure 10. Comparison of INP calculations using different parameterisations. The solid lines show the temperature ranges in which the INP parameterisations are deemed valid, while the dashed lines are extrapolations. The inland aerosol measurements were used as input for the parameterisations, other than for Wilson et al. (2015), where the marine OA concentration was used. The blue and red markers show measured first ice concentrations from 3 August (Taylor et al., 2016) at different cloud-top temperatures.

measurements with continuous-flow diffusion chambers in a variety of environments around the world. Tobo et al. (2013) formed a similar parameterisation (hereafter T13-T) using data measured in a North American pine forest. We used a $D_{\mathrm{p}}>0.5 \mu \mathrm{m}$ concentration of $4.1 \mathrm{~cm}^{-3}$ derived from a combination of the PCASP and CDP measurements during the inland aerosol runs. For comparison, the concentration collected on the filters was $3.5 \mathrm{~cm}^{-3}$, and calculations performed using this number were not discernibly different when plotted in Fig. 10. The INP calculations based on D10 and T13-T both fall within an order of magnitude of the measured first ice concentrations. The T13-T trace is closer to the measured ice concentrations than D10, meaning the ice active fraction during COPE was more similar to that in a forest ecosystem than in the average of the environments studied by DeMott et al. (2010).

Niemand et al. (2012) and DeMott et al. (2015) provide parameterisations (hereafter $\mathrm{N} 12$ and $\mathrm{D} 15$ respectively) base on mineral dusts. N12 uses the integrated mineral dust size distribution to calculate the number of ice surface active sites using measured size distributions, while D15 again simply uses the number concentration of dust particles larger than $0.5 \mu \mathrm{m}$, which in our case was $0.2 \mathrm{~cm}^{-3}$ based on the filter measurements. In a previous study, the concentrations of particles collected on the filters agreed well with in situ probes for particles larger than $0.5 \mu \mathrm{m}$, but the concentrations at smaller 
particle sizes compared poorly (Young et al., 2016). As D15 uses the dust concentration larger than this size, and N12 is based on the dust surface area distribution, which peaks at supermicron sizes, the filter measurements are expected to be a robust measurement for performing these calculations within the uncertainty of the parameterisations. Both mineral dust parameterisations give INP concentrations several orders of magnitude below the measured first ice concentrations.

As well as T13-T, Tobo et al. (2013) constructed a parameterisation (hereafter T13-F) based on measurements of fluorescent particles larger than $0.5 \mu \mathrm{m}$, which are likely to be PBAPs. The measurements upon which this parameterisation was based were made using an ultraviolet aerodynamic particle sizer (UV-APS), which has a different instrument response to the WIBS. Healy et al. (2014) made concurrent measurements using a UV-APS and a WIBS, and found the WIBS channel 3 (which uses the same fluorophore as the UV-APS) was well correlated with the UV-APS fluorescent concentration, but a factor of 2.7 higher due to the instruments' different size ranges.

Between 11:00 and 15:00 UTC on 3 August, the total concentration of fluorescent particles measured by the WIBS was $100 \pm 40 \mathrm{~L}^{-1}$. The fluorescent concentration measured using channel 3 was $50 \pm 26 \mathrm{~L}^{-1}$, which corresponds to a UV-APS equivalent concentration of $19 \pm 10 \mathrm{~L}^{-1}$. Using this concentration in the T13-F parameterisation generates INP concentrations that are also several orders of magnitude lower than the measured ice concentrations. The differences between the predicted INP concentrations based on T13-T and T13-F are due to the different coarse aerosol composition between the forest environment studied in Tobo et al. (2013) and the marine environment studied here, which is likely to have higher concentrations of sea salt. There may be some differences between the PBAP concentrations measured at the ground site to those at the altitude of the aircraft measurements. However, it is unlikely that the PBAP concentrations at $\sim 500 \mathrm{~m}$ would be 3 orders of magnitude higher than at ground level, which is what would be required for the INP concentrations calculated using the T13-F parameterisation to agree with the measured ice concentrations.

As an additional estimate of biological INPs, Möhler et al. (2008) performed chamber experiments using Pseudomonas syringae bacteria and found that the fraction of these bacteria that were active INPs at $-10{ }^{\circ} \mathrm{C}$ was $0.5 \%$. Multiplying this fraction by the PBAP concentration measured by the WIBS gives an INP concentration of $0.5 \mathrm{~L}^{-1}$ at this temperature. As Pseudomonas syringae is amongst the most active biological INPs studied thus far (Lorv et al., 2014), this value may be considered an upper estimate for biological INPs at this temperature. Though it is possible to classify WIBS measurements into different PBAP types, even within simple metaclass discrimination (bacteria, fungal spores, and pollen) the uncertainty in the derived concentrations can be large, e.g. up to a factor of 5 for bacteria, depending on the assumptions used in the analysis approach, as discussed by Crawford et al. (2015).

To date there are no INP parameterisations for soot in the relevant temperature range, and laboratory studies show mixed results, though it is likely that soot particles are less efficient INPs than mineral dust (Hoose and Möhler, 2012). The total mineral dust mass concentration measured was $4 \mu \mathrm{g} \mathrm{m}^{-3}$, whereas the total $\mathrm{BC}$ concentration was $30 \mathrm{ng} \mathrm{m}^{-3}$, so the INP concentrations from BC were likely to have been several orders of magnitude lower than mineral dust.

Wilson et al. (2015) recently published a mass-based parameterisation for marine surface organics measured in the European Arctic. To our knowledge, this is the only parameterisation published for this type of INP. Our results in Fig. 10 show that aerosolised marine surface organics are likely to have produced INPs in similar concentrations to mineral dust and PBAPs.

In summary, both parameterisations based on total aerosol larger than $0.5 \mu \mathrm{m}$ produced INP concentrations of a similar order of magnitude to the measured first ice concentrations. However, all the composition-specific parameterisations produced INP concentrations several orders of magnitude lower. This therefore leaves us with two possible conclusions: there was a source of INPs that was not characterised by our measurements (i.e. a species other than PBAPs, mineral dust, and sea spray OA that were significantly active INPs at $-5>T>-15^{\circ} \mathrm{C}$ ) and/or one or more of the compositionspecific parameterisations underestimate INP concentrations when used in the southwest peninsula of the UK. The ice concentration measurements lie in the temperature range at the high end of most of the parameterisations tested. For example, the data used to generate the fit parameters for T13-F included just seven data points at $-10^{\circ} \mathrm{C}$, and the majority of points were from temperatures $\leq-20^{\circ} \mathrm{C}$. Mason et al. (2015) also noted the poor performance of INP parameterisations at a coastal site, as well as the good correlation of PBAPs with INPs between -15 and $-25^{\circ} \mathrm{C}$ in air from the Pacific Ocean. It is possible the sources of INPs are similar between the two studies, but without further characterisation of INPs active at temperatures higher than $-15^{\circ} \mathrm{C}$, we are limited to such speculation.

\section{Summary and conclusions}

We have presented measurements of boundary layer aerosol concentration, size distribution, and composition from a series of research flights performed over the southwest peninsula of the UK during the COPE campaign of summer 2013. Several case studies showed marine air from the Atlantic Ocean advecting to the peninsula from the south/southwest. The CCN and submicron aerosol in these cases were predominantly sulfate-based, and typical for Atlantic marine air. During easterly winds, polluted air from the UK brought 
urban pollution to the region; the submicron aerosol was composed of ammonium nitrate and organics, and CCN concentrations were several times higher than the marine cases. In one marine case, INP concentrations were estimated by inputting field measurements into several size- and composition-specific parameterisations. Bulk parameterisations predicted INP concentrations within an order of magnitude to measured first ice concentrations, but attempts to identify the composition of the INPs were largely inconclusive.

The periods of southwesterly winds, which brought marine air from the Atlantic to the peninsula, are of particular interest as they are the most conducive to convective cloud formation in the region. The $\mathrm{CCN}$ concentrations in these conditions were $\sim 150-280 \mathrm{~cm}^{-3}$ at $0.1 \%$ SST and $400-500 \mathrm{~cm}^{-3}$ at $0.9 \%$ SST, which are in good agreement with previous measurements in Atlantic air performed at Mace Head (Dall'Osto et al., 2010). The marine aerosol size distributions were also similar to those measured at Mace Head during "clean marine" conditions (Dall'Osto et al., 2011), though some flights had enhanced concentrations of nucleation-mode particles, the source of which is not clear from our measurements.

The majority of accumulation-mode mass was composed of $\mathrm{SO}_{4}$ on these days, which is likely to be from biogenic DMS oxidation (Charlson et al., 1987). The high degree of correlation between $\mathrm{CCN}$ and $\mathrm{SO}$ suggests the $\mathrm{CCN}$ were predominantly composed of $\mathrm{SO}_{4}$, though the origin of these particles (i.e. coated primary or nucleated secondary particles) is again unclear. Accumulation-mode OA had a similar mass spectrum to previous measurements of sea spray OA (Ovadnevaite et al., 2011), but a low correlation with CCN, meaning sea spray $\mathrm{OA}$ that was not internally mixed with $\mathrm{SO}_{4}$ was not a large source of $\mathrm{CCN}$.

By comparing aerosol over the sea to that measured inland, we infer the influence terrestrial emissions had on the marine aerosol. The marine $\mathrm{SO}_{4}$ was acidic over the sea, but was neutralised by terrestrial ammonia, which is likely to have been emitted by agricultural activities that are widespread throughout the peninsula. The increase in inorganics by this process was almost equally balanced out by a decrease in $\mathrm{SO}_{4}$. Consequently, the differences between oceanic and inland $\mathrm{CCN}$ concentrations were less than the day-to-day variability in different marine cases. Additionally, large enhancements of nucleation-mode particles were measured inland, which may also be related to agricultural emissions interacting with marine $\mathrm{H}_{2} \mathrm{SO}_{4}$, but these particles were too small to affect $\mathrm{CCN}$ concentrations.

The largest difference in aerosol mass loadings and CCN were between the marine flights and a case study where polluted urban emissions advected to the site from the east. The $\mathrm{CCN}$ concentrations were $\sim 6$ times higher in this air mass, and the inorganics were composed of equal amounts of ammonium nitrate and sulfate. The difference in $\mathrm{CCN}$ also corresponded to differences in the cloud base CDNC. In the
SWW cases the peak CDNCs were $\sim 450 \mathrm{~cm}^{-3}$, which is in agreement with the CCN measured at $0.9 \% \mathrm{SST}$, though most values of CDNC at cloud base were closer to $300 \mathrm{~cm}^{-3}$, which suggests the SST at cloud base was typically between 0.1 and $0.9 \%$. In the polluted case, the peak CDNC was $\sim 1300 \mathrm{~cm}^{-3}$, which was in agreement with $\mathrm{CCN}$ measured at $0.1 \% \mathrm{SST}$ in this case.

Possible sources of INPs were assessed by comparing various different parameterisations, using our measured aerosol concentrations as input. We estimated INP concentrations using measurements of total aerosol larger than $0.5 \mu \mathrm{m}$ (DeMott et al., 2010; Tobo et al., 2013), mineral dust (DeMott et al., 2015; Niemand et al., 2012), fluorescent aerosol (Möhler et al., 2008; Tobo et al., 2013), and sea spray OA (Wilson et al., 2015). The parameterisations based on total aerosol produced INP concentrations that agreed with measured first ice concentrations within an order of magnitude.

In contrast, the predicted INP concentrations derived using all of the composition-specific parameterisations were several orders of magnitude lower. This must be due to a source of INPs that was not characterised by our measurements and/or one or more of the composition-specific parameterisations tested greatly underestimating INP concentrations when used in the southwest peninsula of the UK. The lowest cloud-top temperatures during COPE were $-15^{\circ} \mathrm{C}$. Better characterisation of INPs at these relatively warm temperatures would be required to gain any further insight into the sources of INPs during COPE. It is, however, very unlikely that the ice concentrations of up to several hundred per litre reported by Taylor et al. (2016) could be achieved without invoking the action of secondary ice processes.

The results presented in this paper serve as information for modellers simulating cloud-aerosol interactions for the COPE project, providing details on the aerosol size, composition, CCN, and INPs in the different case studies. Our data also provide characterisation of Atlantic aerosol and are likely to be particularly applicable to regions where marine air makes landfall in the absence of strong fossil fuel emissions.

\section{Data availability}

Processed data from the FAAM BAe-146 are available from the NCAS British Atmospheric Data Centre at http://catalogue.ceda.ac.uk/uuid/ $8440933238 \mathrm{f} 72 \mathrm{f} 27762005 \mathrm{c} 33 \mathrm{~d} 2 \mathrm{aa} 278$. Raw data from the instrumentation run by the University of Manchester are archived at the university and available upon request. Met Office surface analysis charts are available at http://www1.wetter3.de/Archiv/archiv_ukmet.html.

Acknowledgements. The authors wish to thank all those involved in COPE. The BAe-146-301 Atmospheric Research Aircraft was flown by Directflight Ltd and managed by the Facility for 
Airborne Atmospheric Measurements (FAAM), which is a joint entity of the Natural Environment Research Council (NERC) and the Met Office. COPE was supported by NERC under grant numbers NE/J022594/1 and NE/J023507/1, and the Met Office funded the operation of the BAe-146 FAAM aircraft. We also thank Jurgita Ovadnevaite and colleagues from the National University of Ireland, Galway, for providing the sea spray mass spectrum, and Manuel Dall'Osto of Institute of Marine Sciences, Barcelona, for providing aerosol size distributions from Mace Head for comparison. Finally, we thank the editor and two anonymous referees for helping improve the scientific quality of the manuscript.

Edited by: B. Ervens

Reviewed by: two anonymous referees

\section{References}

Alfarra, M. R.: Insights Into Atmospheric Organic Aerosols Using An Aerosol Mass Spectrometer, University of Manchester Institute of Science and Technology, Manchester, UK, 2004.

Allan, J. D., Jimenez, J. L., Williams, P. I., Alfarra, M. R., Bower, K. N., Jayne, J. T., Coe, H., and Worsnop, D. R.: Quantitative sampling using an Aerodyne aerosol mass spectrometer -1 . Techniques of data interpretation and error analysis, J. Geophys. Res., 108, 4090, doi:10.1029/2002jd002358, 2003.

Allan, J. D., Bower, K. N., Coe, H., Boudries, H., Jayne, J. T., Canagaratna, M. R., Millet, D. B., Goldstein, A. H., Quinn, P. K., Weber, R. J., and Worsnop, D. R.: Submicron aerosol composition at Trinidad Head, California, during ITCT 2K2: Its relationship with gas phase volatile organic carbon and assessment of instrument performance, J. Geophys. Res.-Atmos., 109, D23S24, doi:10.1029/2003JD004208, 2004.

Allan, J. D., Alfarra, M. R., Bower, K. N., Coe, H., Jayne, J. T., Worsnop, D. R., Aalto, P. P., Kulmala, M., Hyötyläinen, T., Cavalli, F., and Laaksonen, A.: Size and composition measurements of background aerosol and new particle growth in a Finnish forest during QUEST 2 using an Aerodyne Aerosol Mass Spectrometer, Atmos. Chem. Phys., 6, 315-327, doi:10.5194/acp-6-315-2006, 2006.

Allan, J. D., Morgan, W. T., Darbyshire, E., Flynn, M. J., Williams, P. I., Oram, D. E., Artaxo, P., Brito, J., Lee, J. D., and Coe, H.: Airborne observations of IEPOX-derived isoprene SOA in the Amazon during SAMBBA, Atmos. Chem. Phys., 14, 1139311407, doi:10.5194/acp-14-11393-2014, 2014.

Almeida, J., Schobesberger, S., Kürten, A., Ortega, I. K., Kupiainen-Määttä, O., Praplan, A. P., Adamov, A., Amorim, A., Bianchi, F., Breitenlechner, M., David, A., Dommen, J., Donahue, N. M., Downard, A., Dunne, E., Duplissy, J., Ehrhart, S., Flagan, R. C., Franchin, A., Guida, R., Hakala, J., Hansel, A., Heinritzi, M., Henschel, H., Jokinen, T., Junninen, H., Kajos, M., Kangasluoma, J., Keskinen, H., Kupc, A., Kurtén, T., Kvashin, A. N., Laaksonen, A., Lehtipalo, K., Leiminger, M., Leppä, J., Loukonen, V., Makhmutov, V., Mathot, S., McGrath, M. J., Nieminen, T., Olenius, T., Onnela, A., Petäjä, T., Riccobono, F., Riipinen, I., Rissanen, M., Rondo, L., Ruuskanen, T., Santos, F. D., Sarnela, N., Schallhart, S., Schnitzhofer, R., Seinfeld, J. H., Simon, M., Sipilä, M., Stozhkov, Y., Stratmann, F., Tomé, A., Tröstl, J., Tsagkogeorgas, G., Vaattovaara, P., Viisanen, Y., Vir- tanen, A., Vrtala, A., Wagner, P. E., Weingartner, E., Wex, H., Williamson, C., Wimmer, D., Ye, P., Yli-Juuti, T., Carslaw, K. S., Kulmala, M., Curtius, J., Baltensperger, U., Worsnop, D. R., Vehkamäki, H., and Kirkby, J.: Molecular understanding of sulphuric acid-amine particle nucleation in the atmosphere, Nature, 502, 359-363, doi:10.1038/nature12663, 2013.

Arnold, S. R., Spracklen, D. V., Williams, J., Yassaa, N., Sciare, J., Bonsang, B., Gros, V., Peeken, I., Lewis, A. C., Alvain, S., and Moulin, C.: Evaluation of the global oceanic isoprene source and its impacts on marine organic carbon aerosol, Atmos. Chem. Phys., 9, 1253-1262, doi:10.5194/acp-9-1253-2009, 2009.

Asmi, A., Wiedensohler, A., Laj, P., Fjaeraa, A.-M., Sellegri, K., Birmili, W., Weingartner, E., Baltensperger, U., Zdimal, V., Zikova, N., Putaud, J.-P., Marinoni, A., Tunved, P., Hansson, H.C., Fiebig, M., Kivekäs, N., Lihavainen, H., Asmi, E., Ulevicius, V., Aalto, P. P., Swietlicki, E., Kristensson, A., Mihalopoulos, N., Kalivitis, N., Kalapov, I., Kiss, G., de Leeuw, G., Henzing, B., Harrison, R. M., Beddows, D., O’Dowd, C., Jennings, S. G., Flentje, H., Weinhold, K., Meinhardt, F., Ries, L., and Kulmala, M.: Number size distributions and seasonality of submicron particles in Europe 2008-2009, Atmos. Chem. Phys., 11, 5505-5538, doi:10.5194/acp-11-5505-2011, 2011.

Augustin-Bauditz, S., Wex, H., Denjean, C., Hartmann, S., Schneider, J., Schmidt, S., Ebert, M., and Stratmann, F.: Laboratorygenerated mixtures of mineral dust particles with biological substances: characterization of the particle mixing state and immersion freezing behavior, Atmos. Chem. Phys., 16, 5531-5543, doi:10.5194/acp-16-5531-2016, 2016.

Bahreini, R., Ervens, B., Middlebrook, A. M., Warneke, C., de Gouw, J. A., DeCarlo, P. F., Jimenez, J. L., Brock, C. A., Neuman, J. A., Ryerson, T. B., Stark, H., Atlas, E., Brioude, J., Fried, A., Holloway, J. S., Peischl, J., Richter, D., Walega, J., Weibring, P., Wollny, A. G., and Fehsenfeld, F. C.: Organic aerosol formation in urban and industrial plumes near Houston and Dallas, Texas, J. Geophys. Res., 114, D00F16, doi:10.1029/2008JD011493, 2009.

Baumgardner, D., Popovicheva, O., Allan, J., Bernardoni, V., Cao, J., Cavalli, F., Cozic, J., Diapouli, E., Eleftheriadis, K., Genberg, P. J., Gonzalez, C., Gysel, M., John, A., Kirchstetter, T. W., Kuhlbusch, T. A. J., Laborde, M., Lack, D., Müller, T., Niessner, R., Petzold, A., Piazzalunga, A., Putaud, J. P., Schwarz, J., Sheridan, P., Subramanian, R., Swietlicki, E., Valli, G., Vecchi, R., and Viana, M.: Soot reference materials for instrument calibration and intercomparisons: a workshop summary with recommendations, Atmos. Meas. Tech., 5, 1869-1887, doi:10.5194/amt-51869-2012, 2012.

Beswick, K. M., Gallagher, M. W., Webb, A. R., Norton, E. G., and Perry, F.: Application of the Aventech AIMMS20AQ airborne probe for turbulence measurements during the Convective Storm Initiation Project, Atmos. Chem. Phys., 8, 5449-5463, doi:10.5194/acp-8-5449-2008, 2008.

Blyth, A. M., Lowenstein, J. H., Huang, Y., Cui, Z., Davies, S., and Carslaw, K. S.: The production of warm rain in shallow maritime cumulus clouds, Q. J. R. Meteorol. Soc., 139, 20-31, doi:10.1002/qj.1972, 2013.

Bohnenstengel, S. I., Belcher, S. E., Aiken, A., Allan, J. D., Allen, G., Bacak, A., Bannan, T. J., Barlow, J. F., Beddows, D. C. S., Bloss, W. J., Booth, A. M., Chemel, C., Coceal, O., Di Marco, C. F., Dubey, M. K., Faloon, K. H., Fleming, Z. L., Furger, M., 
Gietl, J. K., Graves, R. R., Green, D. C., Grimmond, C. S. B., Halios, C. H., Hamilton, J. F., Harrison, R. M., Heal, M. R., Heard, D. E., Helfter, C., Herndon, S. C., Holmes, R. E., Hopkins, J. R., Jones, A. M., Kelly, F. J., Kotthaus, S., Langford, B., Lee, J. D., Leigh, R. J., Lewis, A. C., Lidster, R. T., LopezHilfiker, F. D., McQuaid, J. B., Mohr, C., Monks, P. S., Nemitz, E., Ng, N. L., Percival, C. J., Prévôt, A. S. H., Ricketts, H. M. A., Sokhi, R., Stone, D., Thornton, J. A., Tremper, A. H., Valach, A. C., Visser, S., Whalley, L. K., Williams, L. R., Xu, L., Young, D. E., and Zotter, P.: Meteorology, Air Quality, and Health in London: The ClearfLo Project, B. Am. Meteorol. Soc., 96, 779-804, doi:10.1175/BAMS-D-12-00245.1, 2015.

Burrows, S. M., Hoose, C., Pöschl, U., and Lawrence, M. G.: Ice nuclei in marine air: biogenic particles or dust?, Atmos. Chem. Phys., 13, 245-267, doi:10.5194/acp-13-245-2013, 2013.

Canagaratna, M. R., Jayne, J. T., Jimenez, J. L., Allan, J. D., Alfarra, M. R., Zhang, Q., Onasch, T. B., Drewnick, F., Coe, H., Middlebrook, A., Delia, A., Williams, L. R., Trimborn, A. M., Northway, M. J., DeCarlo, P. F., Kolb, C. E., Davidovits, P., and Worsnop, D. R.: Chemical and microphysical characterization of ambient aerosols with the aerodyne aerosol mass spectrometer, Mass Spectrom. Rev., 26, 185-222, doi:10.1002/mas.20115, 2007.

Cavalli, F., Facchini, M. C., Decesari, S., Mircea, M., Emblico, L., Fuzzi, S., Ceburnis, D., Yoon, Y. J., O’Dowd, C. D., Putaud, J.-P., and Dell'Acqua, A.: Advances in characterization of size-resolved organic matter in marine aerosol over the North Atlantic, J. Geophys. Res.-Atmos., 109, D24215, doi:10.1029/2004JD005137, 2004.

Chang, R. Y.-W., Leck, C., Graus, M., Müller, M., Paatero, J., Burkhart, J. F., Stohl, A., Orr, L. H., Hayden, K., Li, S.-M., Hansel, A., Tjernström, M., Leaitch, W. R., and Abbatt, J. P. D.: Aerosol composition and sources in the central Arctic Ocean during ASCOS, Atmos. Chem. Phys., 11, 10619-10636, doi:10.5194/acp-11-10619-2011, 2011.

Charlson, R. J., Lovelock, J. E., Andreae, M. O., and Warren, S. G.: Oceanic phytoplankton, atmospheric sulphur, cloud albedo and climate, Nature, 326, 655-661, doi:10.1038/326655a0, 1987.

Clark, P., Roberts, N., Lean, H., Ballard, S. P., and Charlton-Perez, C.: Convection-permitting models: a step-change in rainfall forecasting, Meteorol. Appl., 23, 165-181, doi:10.1002/met.1538, 2016.

Connolly, P. J., Möhler, O., Field, P. R., Saathoff, H., Burgess, R., Choularton, T., and Gallagher, M.: Studies of heterogeneous freezing by three different desert dust samples, Atmos. Chem. Phys., 9, 2805-2824, doi:10.5194/acp-9-2805-2009, 2009.

Crawford, I., Ruske, S., Topping, D. O., and Gallagher, M. W.: Evaluation of hierarchical agglomerative cluster analysis methods for discrimination of primary biological aerosol, Atmos. Meas. Tech., 8, 4979-4991, doi:10.5194/amt-8-4979-2015, 2015.

Cross, E. S., Slowik, J. G., Davidovits, P., Allan, J. D., Worsnop, D. R., Jayne, J. T., Lewis, D. K., Canagaratna, M., and Onasch, T. B.: Laboratory and ambient particle density determinations using light scattering in conjunction with aerosol mass spectrometry, Aerosol Sci. Tech., 41, 343-359, doi:10.1080/02786820701199736, 2007.

Dall'Osto, M., Ceburnis, D., Martucci, G., Bialek, J., Dupuy, R., Jennings, S. G., Berresheim, H., Wenger, J., Healy, R., Facchini, M. C., Rinaldi, M., Giulianelli, L., Finessi, E., Worsnop, D., Ehn,
M., Mikkilä, J., Kulmala, M., and O’Dowd, C. D.: Aerosol properties associated with air masses arriving into the North East Atlantic during the 2008 Mace Head EUCAARI intensive observing period: an overview, Atmos. Chem. Phys., 10, 8413-8435, doi:10.5194/acp-10-8413-2010, 2010.

Dall'Osto, M., Monahan, C., Greaney, R., Beddows, D. C. S., Harrison, R. M., Ceburnis, D., and O'Dowd, C. D.: A statistical analysis of North East Atlantic (submicron) aerosol size distributions, Atmos. Chem. Phys., 11, 12567-12578, doi:10.5194/acp11-12567-2011, 2011.

Decesari, S., Finessi, E., Rinaldi, M., Paglione, M., Fuzzi, S., Stephanou, E. G., Tziaras, T., Spyros, A., Ceburnis, D., O’Dowd, C., Dall'Osto, M., Harrison, R. M., Allan, J., Coe, H., and Facchini, M. C.: Primary and secondary marine organic aerosols over the North Atlantic Ocean during the MAP experiment, J. Geophys. Res. Atmos., 116, 2156-2202, 2011.

DeMott, P. J., Prenni, A. J., Liu, X., Kreidenweis, S. M., Petters, M. D., Twohy, C. H., Richardson, M. S., Eidhammer, T., and Rogers, D. C.: Predicting global atmospheric ice nuclei distributions and their impacts on climate, P. Natl. Acad. Sci. USA, 107, 1121722, doi:10.1073/pnas.0910818107, 2010.

DeMott, P. J., Prenni, A. J., McMeeking, G. R., Sullivan, R. C., Petters, M. D., Tobo, Y., Niemand, M., Möhler, O., Snider, J. R., Wang, Z., and Kreidenweis, S. M.: Integrating laboratory and field data to quantify the immersion freezing ice nucleation activity of mineral dust particles, Atmos. Chem. Phys., 15, 393-409, doi:10.5194/acp-15-393-2015, 2015.

Diehl, K., Simmel, M., and Wurzler, S.: Numerical sensitivity studies on the impact of aerosol properties and drop freezing modes on the glaciation, microphysics, and dynamics of clouds, J. Geophys. Res., 111, D07202, doi:10.1029/2005JD005884, 2006.

Drewnick, F., Hings, S. S., DeCarlo, P., Jayne, J. T., Gonin, M., Fuhrer, K., Weimer, S., Jimenez, J. L., Demerjian, K. L., Borrmann, S., and Worsnop, D. R.: A New Time-of-Flight Aerosol Mass Spectrometer (TOF-AMS)-Instrument Description and First Field Deployment, Aerosol Sci. Tech., 39, 637-658, doi:10.1080/02786820500182040, 2005.

Drewnick, F., Diesch, J.-M., Faber, P., and Borrmann, S.: Aerosol mass spectrometry: particle-vaporizer interactions and their consequences for the measurements, Atmos. Meas. Tech., 8, 38113830, doi:10.5194/amt-8-3811-2015, 2015.

Fan, J., Zhang, R., Li, G., and Tao, W.-K.: Effects of aerosols and relative humidity on cumulus clouds, J. Geophys. Res., 112, D14204, doi:10.1029/2006JD008136, 2007.

Formenti, P., Rajot, J. L., Desboeufs, K., Caquineau, S., Chevaillier, S., Nava, S., Gaudichet, A., Journet, E., Triquet, S., Alfaro, S., Chiari, M., Haywood, J., Coe, H., and Highwood, E.: Regional variability of the composition of mineral dust from western Africa: Results from the AMMA SOP0/DABEX and DODO field campaigns, J. Geophys. Res., 113, D00C13, doi:10.1029/2008JD009903, 2008.

Gantt, B. and Meskhidze, N.: The physical and chemical characteristics of marine primary organic aerosol: a review, Atmos. Chem. Phys., 13, 3979-3996, doi:10.5194/acp-13-3979-2013, 2013.

Gerbig, C., Schmitgen, S., Kley, D., Volz-Thomas, A., Dewey, K., and Haaks, D.: An improved fast-response vacuum-UV resonance fluorescence CO instrument, J. Geophys. Res., 104, 1699, doi:10.1029/1998JD100031, 1999. 
Gershey, R. M.: Characterization of seawater organic matter carried by bubble-generated aerosols, Limnol. Oceanogr., 28, 309-319, doi:10.4319/lo.1983.28.2.0309, 1983.

Golding, B. (Ed.): Boscastle and north Cornwall post flood event study-meteorological analysis of the conditions leading to flooding on 16 August 2004, Met Office, 2005.

Golding, B., Clark, P., and May, B.: The Boscastle flood: Meteorological analysis of the conditions leading to flooding on $16 \mathrm{Au}-$ gust 2004, Weather, 60, 230-235, doi:10.1256/wea.71.05, 2005.

Hand, V. L., Capes, G., Vaughan, D. J., Formenti, P., Haywood, J. M., and Coe, H.: Evidence of internal mixing of African dust and biomass burning particles by individual particle analysis using electron beam techniques, J. Geophys. Res., 115, D13301, doi:10.1029/2009JD012938, 2010.

Harrison, R. M. and Pio, C. A.: Size-differentiated composition of inorganic atmospheric aerosols of both marine and polluted continental origin, Atmos. Environ., 17, 1733-1738, doi:10.1016/0004-6981(83)90180-4, 1983.

Healy, D. A., O'Connor, D. J., and Sodeau, J. R.: Measurement of the particle counting efficiency of the "Waveband Integrated Bioaerosol Sensor" model number 4 (WIBS-4), J. Aerosol Sci., 47, 94-99, doi:10.1016/j.jaerosci.2012.01.003, 2012.

Healy, D. A., Huffman, J. A., O'Connor, D. J., Pöhlker, C., Pöschl, U., and Sodeau, J. R.: Ambient measurements of biological aerosol particles near Killarney, Ireland: a comparison between real-time fluorescence and microscopy techniques, Atmos. Chem. Phys., 14, 8055-8069, doi:10.5194/acp-14-80552014, 2014.

Hering, S. V., Stolzenburg, M. R., Quant, F. R., Oberreit, D. R., and Keady, P. B.: A Laminar-Flow, Water-Based Condensation Particle Counter (WCPC), Aerosol Sci. Tech., 39, 659-672, 2005.

Hoose, C. and Möhler, O.: Heterogeneous ice nucleation on atmospheric aerosols: a review of results from laboratory experiments, Atmos. Chem. Phys., 12, 9817-9854, doi:10.5194/acp-12-98172012, 2012.

Hoppel, W. A., Frick, G. M., and Larson, R. E.: Effect of nonprecipitating clouds on the aerosol size distribution in the marine boundary layer, Geophys. Res. Lett., 13, 125-128, doi:10.1029/GL013i002p00125, 1986.

Huang, Y., Blyth, A. M., Brown, P. R. A., Choularton, T. W., Connolly, P., Gadian, A. M., Jones, H., Latham, J., Cui, Z., and Carslaw, K.: The development of ice in a cumulus cloud over southwest England, New J. Phys., 10, 105021, doi:10.1088/1367-2630/10/10/105021, 2008.

Huebert, B. J., Zhuang, L., Howell, S., Noone, K., and Noone, B.: Sulfate, nitrate, methanesulfonate, chloride, ammonium, and sodium measurements from ship, island, and aircraft during the Atlantic Stratocumulus Transition Experiment/Marine Aerosol Gas Exchange, J. Geophys. Res., 101, 4413, doi:10.1029/95JD02044, 1996.

Huffman, J. A., Treutlein, B., and Pöschl, U.: Fluorescent biological aerosol particle concentrations and size distributions measured with an Ultraviolet Aerodynamic Particle Sizer (UVAPS) in Central Europe, Atmos. Chem. Phys., 10, 3215-3233, doi:10.5194/acp-10-3215-2010, 2010.

Jensen, T. L., Kreidenweis, S. M., Kim, Y., Sievering, H., and Pszenny, A.: Aerosol distributions in the North Atlantic marine boundary layer during Atlantic Stratocumulus Transition Exper-
iment/Marine Aerosol and Gas Exchange, J. Geophys. Res., 101, 4455, doi:10.1029/95JD00506, 1996.

Jimenez, J. L., Canagaratna, M. R., Donahue, N. M., Prevot, A. S. H., Zhang, Q., Kroll, J. H., DeCarlo, P. F., Allan, J. D., Coe, H., Ng, N. L., Aiken, A. C., Docherty, K. S., Ulbrich, I. M., Grieshop, A. P., Robinson, A. L., Duplissy, J., Smith, J. D., Wilson, K. R., Lanz, V. A., Hueglin, C., Sun, Y. L., Tian, J., Laaksonen, A., Raatikainen, T., Rautiainen, J., Vaattovaara, P., Ehn, M., Kulmala, M., Tomlinson, J. M., Collins, D. R., Cubison, M. J., Dunlea, J., Huffman, J. A., Onasch, T. B., Alfarra, M. R., Williams, P. I., Bower, K., Kondo, Y., Schneider, J., Drewnick, F., Borrmann, S., Weimer, S., Demerjian, K., Salcedo, D., Cottrell, L., Griffin, R., Takami, A., Miyoshi, T., Hatakeyama, S., Shimono, A., Sun, J. Y., Zhang, Y. M., Dzepina, K., Kimmel, J. R., Sueper, D., Jayne, J. T., Herndon, S. C., Trimborn, A. M., Williams, L. R., Wood, E. C., Middlebrook, A. M., Kolb, C. E., Baltensperger, U., and Worsnop, D. R.: Evolution of Organic Aerosols in the Atmosphere, Science, 326, 1525-1529, 2009.

Johnson, D. B.: The Role of Giant and Ultragiant Aerosol Particles in Warm Rain Initiation, J. Atmos. Sci., 39, 448-460, doi:10.1175/1520-0469(1982)039<0448:TROGAU>2.0.CO;2, 1982.

Klett, J. D. and Davis, M. H.: Theoretical Collision Efficiencies of Cloud Droplets at Small Reynolds Numbers, J. Atmos. Sci., 30, 107-117, doi:10.1175/15200469(1973)030<0107:TCEOCD>2.0.CO;2, 1973.

Koren, I., Kaufman, Y. J., Rosenfeld, D., Remer, L. A., and Rudich, Y.: Aerosol invigoration and restructuring of Atlantic convective clouds, Geophys. Res. Lett., 32, L14828, doi:10.1029/2005GL023187, 2005.

Laborde, M., Mertes, P., Zieger, P., Dommen, J., Baltensperger, U., and Gysel, M.: Sensitivity of the Single Particle Soot Photometer to different black carbon types, Atmos. Meas. Tech., 5, 10311043, doi:10.5194/amt-5-1031-2012, 2012a.

Laborde, M., Schnaiter, M., Linke, C., Saathoff, H., Naumann, K.H., Möhler, O., Berlenz, S., Wagner, U., Taylor, J. W., Liu, D., Flynn, M., Allan, J. D., Coe, H., Heimerl, K., Dahlkötter, F., Weinzierl, B., Wollny, A. G., Zanatta, M., Cozic, J., Laj, P., Hitzenberger, R., Schwarz, J. P., and Gysel, M.: Single Particle Soot Photometer intercomparison at the AIDA chamber, Atmos. Meas. Tech., 5, 3077-3097, doi:10.5194/amt-5-3077-2012, 2012b.

Langley, L., Leaitch, W. R., Lohmann, U., Shantz, N. C., and Worsnop, D. R.: Contributions from DMS and ship emissions to CCN observed over the summertime North Pacific, Atmos. Chem. Phys., 10, 1287-1314, doi:10.5194/acp-10-1287-2010, 2010.

Leon, D. C., French, J. R., Lasher-Trapp, S., Blyth, A. M., Abel, S. J., Ballard, S., Barrett, A., Bennett, L. J., Bower, K., Brooks, B., Brown, P., Charlton-Perez, C., Choularton, T., Clark, P., Collier, C., Crosier, J., Cui, Z., Dey, S., Dufton, D., Eagle, C., Flynn, M. J., Gallagher, M., Halliwell, C., Hanley, K., Hawkness-Smith, L., Huang, Y., Kelly, G., Kitchen, M., Korolev, A., Lean, H., Liu, Z., Marsham, J., Moser, D., Nicol, J., Norton, E. G., Plummer, D., Price, J., Ricketts, H., Roberts, N., Rosenberg, P. D., Simonin, D., Taylor, J. W., Warren, R., Williams, P. I. and Young, G.: The COnvective Precipitation Experiment (COPE): Investigating the origins of heavy precipitation in the southwestern UK, Bull. 
Am. Meteorol. Soc., 97, 1003-1020, doi:10.1175/BAMS-D-1400157.1, 2016.

Liu, P. S. K., Leaitch, W. R., Banic, C. M., Li, S.-M., Ngo, D., and Megaw, W. J.: Aerosol observations at Chebogue Point during the 1993 North Atlantic Regional Experiment: Relationships among cloud condensation nuclei, size distribution, and chemistry, J. Geophys. Res., 101, 28971, doi:10.1029/96JD00445, 1996.

Lorv, J. S. H., Rose, D. R., and Glick, B. R.: Bacterial ice crystal controlling proteins, Scientifica (Cairo), 2014, 976895, doi:10.1155/2014/976895, 2014.

Mason, R. H., Si, M., Li, J., Chou, C., Dickie, R., Toom-Sauntry, D., Pöhlker, C., Yakobi-Hancock, J. D., Ladino, L. A., Jones, K., Leaitch, W. R., Schiller, C. L., Abbatt, J. P. D., Huffman, J. A., and Bertram, A. K.: Ice nucleating particles at a coastal marine boundary layer site: correlations with aerosol type and meteorological conditions, Atmos. Chem. Phys., 15, 12547-12566, doi:10.5194/acp-15-12547-2015, 2015.

Middlebrook, A. M., Bahreini, R., Jimenez, J. L., and Canagaratna, M. R.: Evaluation of Composition-Dependent Collection Efficiencies for the Aerodyne Aerosol Mass Spectrometer using Field Data, Aerosol Sci. Tech., 46, 258-271, doi:10.1080/02786826.2011.620041, 2012.

Möhler, O., Georgakopoulos, D. G., Morris, C. E., Benz, S., Ebert, V., Hunsmann, S., Saathoff, H., Schnaiter, M., and Wagner, R.: Heterogeneous ice nucleation activity of bacteria: new laboratory experiments at simulated cloud conditions, Biogeosciences, 5, 1425-1435, doi:10.5194/bg-5-1425-2008, 2008.

Morgan, W. T., Allan, J. D., Bower, K. N., Highwood, E. J., Liu, D., McMeeking, G. R., Northway, M. J., Williams, P. I., Krejci, R., and Coe, H.: Airborne measurements of the spatial distribution of aerosol chemical composition across Europe and evolution of the organic fraction, Atmos. Chem. Phys., 10, 4065-4083, doi:10.5194/acp-10-4065-2010, 2010.

Morgan, W. T., Ouyang, B., Allan, J. D., Aruffo, E., Di Carlo, P., Kennedy, O. J., Lowe, D., Flynn, M. J., Rosenberg, P. D., Williams, P. I., Jones, R., McFiggans, G. B., and Coe, H.: Influence of aerosol chemical composition on $\mathrm{N}_{2} \mathrm{O}_{5}$ uptake: airborne regional measurements in northwestern Europe, Atmos. Chem. Phys., 15, 973-990, doi:10.5194/acp-15-973-2015, 2015.

Morton, D., Rowland, C. S., Wood, C. M., Meek, L., Marston, C., Smith, G., Wadsworth, R. A., and Simpson, I. C.: Final Report for LCM2007 - the new UK land cover map, Countryside Survey Technical Report No 11/07, 2011.

Murray, B. J., O’Sullivan, D., Atkinson, J. D., and Webb, M. E.: Ice nucleation by particles immersed in supercooled cloud droplets., Chem. Soc. Rev., 41, 6519-54, doi:10.1039/c2cs35200a, 2012.

Ng, N. L., Canagaratna, M. R., Zhang, Q., Jimenez, J. L., Tian, J., Ulbrich, I. M., Kroll, J. H., Docherty, K. S., Chhabra, P. S., Bahreini, R., Murphy, S. M., Seinfeld, J. H., Hildebrandt, L., Donahue, N. M., DeCarlo, P. F., Lanz, V. A., Prévôt, A. S. H., Dinar, E., Rudich, Y., and Worsnop, D. R.: Organic aerosol components observed in Northern Hemispheric datasets from Aerosol Mass Spectrometry, Atmos. Chem. Phys., 10, 46254641, doi:10.5194/acp-10-4625-2010, 2010.

Niemand, M., Möhler, O., Vogel, B., Vogel, H., Hoose, C., Connolly, P., Klein, H., Bingemer, H., DeMott, P., Skrotzki, J., and Leisner, T.: A Particle-Surface-Area-Based Parameterization of
Immersion Freezing on Desert Dust Particles, J. Atmos. Sci., 69, 3077-3092, doi:10.1175/JAS-D-11-0249.1, 2012.

Nuaaman, I., Li, S.-M., Hayden, K. L., Onasch, T. B., Massoli, P., Sueper, D., Worsnop, D. R., Bates, T. S., Quinn, P. K., and McLaren, R.: Separating refractory and non-refractory particulate chloride and estimating chloride depletion by aerosol mass spectrometry in a marine environment, Atmos. Chem. Phys. Discuss., 15, 2085-2118, doi:10.5194/acpd-15-2085-2015, 2015.

O'Dowd, C. D. and de Leeuw, G.: Marine aerosol production: a review of the current knowledge, Philos. T. R. Soc. A., 365, 17531774, doi:10.1098/rsta.2007.2043, 2007.

O'Dowd, C., Monahan, C., and Dall'Osto, M.: On the occurrence of open ocean particle production and growth events, Geophys. Res. Lett., 37, L19805, doi:10.1029/2010GL044679, 2010.

O’Dowd, C., Ceburnis, D., Ovadnevaite, J., Vaishya, A., Rinaldi, M., and Facchini, M. C.: Do anthropogenic, continental or coastal aerosol sources impact on a marine aerosol signature at Mace Head?, Atmos. Chem. Phys., 14, 10687-10704, doi:10.5194/acp-14-10687-2014, 2014.

O'Dowd, C. D., Smith, M. H., Consterdine, I. E., and Lowe, J. A.: Marine aerosol, sea-salt, and the marine sulphur cycle: a short review, Atmos. Environ., 31, 73-80, doi:10.1016/S13522310(96)00106-9, 1997.

Ovadnevaite, J., O’Dowd, C., Dall'Osto, M., Ceburnis, D., Worsnop, D. R., and Berresheim, H.: Detecting high contributions of primary organic matter to marine aerosol: A case study, Geophys. Res. Lett., 38, L02807, doi:10.1029/2010GL046083, 2011.

Ovadnevaite, J., Ceburnis, D., Canagaratna, M., Berresheim, H., Bialek, J., Martucci, G., Worsnop, D. R., and O'Dowd, C.: On the effect of wind speed on submicron sea salt mass concentrations and source fluxes, J. Geophys. Res., 117, D16201, doi:10.1029/2011JD017379, 2012.

Ovadnevaite, J., Ceburnis, D., Leinert, S., Dall'Osto, M., Canagaratna, M., O'Doherty, S., Berresheim, H., and O'Dowd, C.: Submicron NE Atlantic marine aerosol chemical composition and abundance: Seasonal trends and air mass categorization, J. Geophys. Res.-Atmos., 119, 11850-11863, doi:10.1002/2013JD021330, 2014.

Phillips, V. T. J., Blyth, A. M., Brown, P. R. A., Choularton, T. W., and Latham, J.: The glaciation of a cumulus cloud over New Mexico, Q. J. Roy. Meteor. Soc., 127, 1513-1534, doi:10.1002/qj.49712757503, 2001.

Phinney, L., Richard Leaitch, W., Lohmann, U., Boudries, H., Worsnop, D. R., Jayne, J. T., Toom-Sauntry, D., Wadleigh, M., Sharma, S., and Shantz, N.: Characterization of the aerosol over the sub-arctic north east Pacific Ocean, Deep-Sea Res. Pt II, 53, 2410-2433, doi:10.1016/j.dsr2.2006.05.044, 2006.

Pierce, J. R., Chen, K., and Adams, P. J.: Contribution of primary carbonaceous aerosol to cloud condensation nuclei: processes and uncertainties evaluated with a global aerosol microphysics model, Atmos. Chem. Phys., 7, 5447-5466, doi:10.5194/acp-75447-2007, 2007.

Pirjola, L., O'Dowd, C. D., Brooks, I. M., and Kulmala, M.: Can new particle formation occur in the clean marine boundary layer?, J. Geophys. Res., 105, 26531, doi:10.1029/2000JD900310, 2000.

Politovich, M. K. and Cooper, W. A.: Variability of the Supersaturation in Cumulus Clouds, J. Atmos. Sci., 45, 1651-1664, 
doi:10.1175/1520-0469(1988)045<1651:VOTSIC>2.0.CO;2, 1988.

Pouleur, S., Richard, C., Martin, J.-G., and Antoun, H.: Ice Nucleation Activity in Fusarium acuminatum and Fusarium avenaceum, Appl. Environ. Microbiol., 58, 2960-2964, 1992.

Quinn, P. K., Barrett, K. J., Dentener, F. J., Lipschultz, F., and Six, K. D.: Estimation of the air/sea exchange of ammonia for the North Atlantic Basin, Biogeochemistry, 35, 275-304, doi:10.1007/BF02179831, 1996.

Roberts, G. C. and Nenes, A.: A Continuous-Flow Streamwise Thermal-Gradient $\mathrm{CCN}$ Chamber for Atmospheric Measurements, Aerosol Sci. Tech., 39, 206-221, doi:10.1080/027868290913988, 2005.

Roberts, G. C., Day, D. A., Russell, L. M., Dunlea, E. J., Jimenez, J. L., Tomlinson, J. M., Collins, D. R., Shinozuka, Y., and Clarke, A. D.: Characterization of particle cloud droplet activity and composition in the free troposphere and the boundary layer during INTEX-B, Atmos. Chem. Phys., 10, 6627-6644, doi:10.5194/acp-10-6627-2010, 2010.

Rollins, A. W., Fry, J. L., Hunter, J. F., Kroll, J. H., Worsnop, D. R., Singaram, S. W., and Cohen, R. C.: Elemental analysis of aerosol organic nitrates with electron ionization high-resolution mass spectrometry, Atmos. Meas. Tech., 3, 301-310, doi:10.5194/amt3-301-2010, 2010.

Rosenberg, P. D., Dean, A. R., Williams, P. I., Dorsey, J. R., Minikin, A., Pickering, M. A., and Petzold, A.: Particle sizing calibration with refractive index correction for light scattering optical particle counters and impacts upon PCASP and CDP data collected during the Fennec campaign, Atmos. Meas. Tech., 5, 1147-1163, doi:10.5194/amt-5-1147-2012, 2012.

Schmale, J., Schneider, J., Nemitz, E., Tang, Y. S., Dragosits, U., Blackall, T. D., Trathan, P. N., Phillips, G. J., Sutton, M., and Braban, C. F.: Sub-Antarctic marine aerosol: dominant contributions from biogenic sources, Atmos. Chem. Phys., 13, 86698694, doi:10.5194/acp-13-8669-2013, 2013.

Schwarz, J. P., Spackman, J. R., Gao, R. S., Perring, A. E., Cross, E., Onasch, T. B., Ahern, A., Wrobel, W., Davidovits, P., Olfert, J., Dubey, M. K., Mazzoleni, C., and Fahey, D. W.: The Detection Efficiency of the Single Particle Soot Photometer, Aerosol Sci. Tech., 44, 612-628, doi:10.1080/02786826.2010.481298, 2010.

Seinfeld, J. H. and Pandis, S. N.: Atmospheric Chemistry and Physics - From Air Pollution to Climate Change, 2nd Edn., John Wiley \& Sons, New York, 1998.

Slowik, J. G., Stroud, C., Bottenheim, J. W., Brickell, P. C., Chang, R. Y.-W., Liggio, J., Makar, P. A., Martin, R. V., Moran, M. D., Shantz, N. C., Sjostedt, S. J., van Donkelaar, A., Vlasenko, A., Wiebe, H. A., Xia, A. G., Zhang, J., Leaitch, W. R., and Abbatt, J. P. D.: Characterization of a large biogenic secondary organic aerosol event from eastern Canadian forests, Atmos. Chem. Phys., 10, 2825-2845, doi:10.5194/acp-10-2825-2010, 2010.

Spracklen, D. V. and Heald, C. L.: The contribution of fungal spores and bacteria to regional and global aerosol number and ice nucleation immersion freezing rates, Atmos. Chem. Phys., 14, 90519059, doi:10.5194/acp-14-9051-2014, 2014.

Stein, A. F., Draxler, R. R., Rolph, G. D., Stunder, B. J. B., Cohen, M. D. and Ngan, F.: NOAA's HYSPLIT Atmospheric Transport and Dispersion Modeling System, Bull. Am. Meteorol. Soc., 96, 2059-2077, doi:10.1175/BAMS-D-14-00110.1, 2015.
Sutton, M. A., Tang, Y. S., Dragosits, U., Fournier, N., Dore, A. J., Smith, R. I., Weston, K. J., and Fowler, D.: A spatial analysis of atmospheric ammonia and ammonium in the U.K., Scientific World Journal, 1, 275-86, doi:10.1100/tsw.2001.313, 2001.

Taylor, J. W., Allan, J. D., Allen, G., Coe, H., Williams, P. I., Flynn, M. J., Le Breton, M., Muller, J. B. A., Percival, C. J., Oram, D., Forster, G., Lee, J. D., Rickard, A. R., Parrington, M., and Palmer, P. I.: Size-dependent wet removal of black carbon in Canadian biomass burning plumes, Atmos. Chem. Phys., 14, 13755-13771, doi:10.5194/acp-14-13755-2014, 2014.

Taylor, J. W., Choularton, T. W., Blyth, A. M., Liu, Z., Bower, K. N., Crosier, J., Gallagher, M. W., Williams, P. I., Dorsey, J. R., Flynn, M. J., Bennett, L. J., Huang, Y., French, J., Korolev, A., and Brown, P. R. A.: Observations of cloud microphysics and ice formation during COPE, Atmos. Chem. Phys., 16, 799-826, doi:10.5194/acp-16-799-2016, 2016.

Tobo, Y., Prenni, A. J., DeMott, P. J., Huffman, J. A., McCluskey, C. S., Tian, G., Pöhlker, C., Pöschl, U., and Kreidenweis, S. M.: Biological aerosol particles as a key determinant of ice nuclei populations in a forest ecosystem, J. Geophys. Res.-Atmos., 118, 10100-10110, doi:10.1002/jgrd.50801, 2013.

Topping, D., Connolly, P., and McFiggans, G.: Cloud droplet number enhanced by co-condensation of organic vapours, Nat. Geosci., 6, 443-446, doi:10.1038/ngeo1809, 2013.

Trembath, J.: Airborne CCN measurements, University of Manchester, PhD Thesis, 2013.

Trembath, J., Bart, M., and Brooke, J.: Efficiencies of Modified Rosemount Housings for sampling Aerosol on a Fast Atmospheric Research Aircraft, FAAM Tech. Note, available at: http://www.faam.ac.uk/index.php/faam-documents/ science-instruments/1673-inlet-efficiency (last access: $16 \mathrm{Au}-$ gust 2016), 2012.

Wang, S. C. and Flagan, R. C.: Scanning Electrical Mobility Spectrometer, Aerosol Sci. Tech., 13, 230-240, 1990.

Warren, R. A., Kirshbaum, D. J., Plant, R. S., and Lean, H. W.: A "Boscastle-type" quasi-stationary convective system over the UK Southwest Peninsula, Q. J. Roy. Meteor. Soc., 140, 240-257, doi:10.1002/qj.2124, 2014.

Wilson, T. W., Ladino, L. A., Alpert, P. A., Breckels, M. N., Brooks, I. M., Browse, J., Burrows, S. M., Carslaw, K. S., Huffman, J. A., Judd, C., Kilthau, W. P., Mason, R. H., McFiggans, G., Miller, L. A., Nájera, J. J., Polishchuk, E., Rae, S., Schiller, C. L., Si, M., Temprado, J. V., Whale, T. F., Wong, J. P. S., Wurl, O., Yakobi-Hancock, J. D., Abbatt, J. P. D., Aller, J. Y., Bertram, A. K., Knopf, D. A., and Murray, B. J.: A marine biogenic source of atmospheric ice-nucleating particles, Nature, 525, 234-238, doi:10.1038/nature14986, 2015.

Young, G., Jones, H. M., Darbyshire, E., Baustian, K. J., McQuaid, J. B., Bower, K. N., Connolly, P. J., Gallagher, M. W., and Choularton, T. W.: Size-segregated compositional analysis of aerosol particles collected in the European Arctic during the ACCACIA campaign, Atmos. Chem. Phys., 16, 4063-4079, doi:10.5194/acp-16-4063-2016, 2016.

Zorn, S. R.: Chemical composition measurements of pristine aerosols in the southern atlantic and amazonian regions by means of on-line time-of-flight aerosol mass spectrometry, Johannes Gutenberg-University Mainz, 2009. 